\title{
SEARCH AND SEIZURE IN THE SUPREME COURT: SHADOWS ON THE FOURTH AMENDMENT $\dagger$
}

$\mathrm{T}$ WWo RECENT United States Supreme Court decisions have greatly extended the scope of the federal law of search and seizure. Yet a decade has passed since the Court has reworked fourth amendment theory. In pitching a tent, it is hazardous to lengthen one's ropes without strengthening one's stakes.

At the end of the 1959 Term, the Court, in Elkins v. United States, held that "evidence obtained by state officers during a search which, if conducted by federal officers, would have violated the defendant's immunity from unreasonable searches and seizures under the Fourth Amendment is inadmissible ... in a federal criminal trial."1 The familiar "silver platter doctrine"2 was thus discarded. But, by implication, Elkins introduced an even more important principle. The decision was clearly founded on the notion that state searches which, if conducted by federal officers would violate the fourth amendment, were searches in violation of the due process clause of the fourteenth. 3 No longer was merely "the core of the Fourth Amendment" enforceable against the states. ${ }^{4}$ Fourth and fourteenth amendment standards of reasonable search and seizure were assumed to be identical.

In Mapp v. Ohio, 5 decided last Term, the Court made effective the substantive expansion of federal search and seizure law wrought in Elkins. "We hold," said Mr. Justice Clark, "that all evidence obtained by searches and seizures in violation of the Constitution is, by that same authority, inadmissible in a state court."6 The federal exclusionary rule was thus grounded in the Constitution and made binding on the states through the due process

$\dagger$ The Review will from time to time publish in this space longer and more extensive work of general interest contributed by members of its Editorial Board.

1364 U.S. 209, 223 (1960).

2 See Weeks v. United States, 232 U.S. 383, 398 (1914); Byars v. United States, 273 U.S. 28, 33 (1927); Kamisar, Wolf and Lustig Ten Years Later: Illegal State Evidence in State and Federal Courts, 43 MrN. L. REv. 1083 (1959).

3 "As the Court's rule only purports to exclude evidence seized by state officers in violation of the Constitution, it is plain that the Court assumes for the purposes of these cases that, as a consequence of Wolf, precisely the same rules are applicable in determining whether the conduct of state officials violates the Constitution as are applicable in determining whether the conduct of federal officials does so. . ." Elkins v. United States, 364 U.S. 209, 237 (1960) (Frankfurter, J., dissenting).

4 See Wolf v. Colorado, 338 U.S. 25, 27 (1949).

5367 U.S. 643 (1961).

6 Id. at 655. 
clause. At the same time, the Elkins extension of substantive fourth amendment standards to the states was acknowledged: "Federal-state cooperation in the solution of crime under constitutional standards will be promoted, if only by recognition of their now mutual obligation to respect the same fundamental criteria in their approaches." 7

As a result of Elkins and Mapp twenty-four states which, in the absence of any exclusionary rule, have had little occasion to consider the law of search and seizure, must now conform to federal standards in securing evidence to be used in criminal trials. 8 Even the remaining states which already employ some form of exclusionary rule must adjust their substantive law to conform to fourth amendment requirements.

It is appropriate, at the threshold of an era in which Supreme Court interpretations of the fourth amendment will affect the daily operations of police and courts throughout the land, to reexamine the theory revealed in those interpretations.

In the past two decades, Supreme Court search and seizure cases have been characterized by conflict, confusion, and even bitterness. 9 The struggles have centered on a variety of issues: the relation between search warrants and the requirement of reasonableness; ${ }^{10}$ the evidence necessary to constitute probable cause sufficient to justify either arrest or the issuance of a warrant;11 the scope of lawful search incident to a valid arrest; 12 and, of course, the substance and enforceability of constitutional restrictions on searches by state

$7 \mathrm{Id}$. at 658 .

8 For a list of those states which had not, by 1960, adopted any form of exclusionary rule, see Elkins v. United States, 364 U.S. 209, 224-25 (1960) (Appendix to Opinion of the Court, Table I).

9 Members of the Court have often referred to the conflicting pattern of decisions. See, e.g., Trupiano v. United States, 334 U.S. 699, 716 (1948) ("At best, the operation of the rule which the Court today enunciates for the first time may be expected to confound confusion in a field already replete with complexities.") (Vinson, C. J., dissenting); United States v. Rabinowitz 339 U.S. 56, 67 (1950) ("In no other field has the law's uncertainty been more clearly manifested.") (Black, J., dissenting); Chapman v. United States, 365 U.S. 610, 618 (1961) ("The course of true law pertaining to searches and seizures, as enunciated here, has not-to put it mildly-run smooth. The Court's opinion in this case is hardly calculated, I regret to say, to contribute to clarification.") (Frankfurter, J., concurring); ("For some years now the field has been muddy, but today the Court makes it a quagmire.") (Clark, J., dissenting). $I d$. at 622.

10 See, e.g., Trupiano v. United States, 334 U.S. 699 (1948); United States v. Rabinowitz, 339 U.S. 56 (1950); Reynard, Freedom from Unreasonable Search and Seizure-A Second Class Constitutional Right ? 25 IND. L.J. 259 (1950).

11 See, e.g., Draper v. United States, 358 U.S. 307 (1959); Henry v. United States, 361 U.S. 98 (1959); Giordenello v. United States, 357 U.S. 480 (1958); Barrett, Personal Rights, Property Rights, and the Fourth Amendment, 1960 SUP. CT. REv. 46.

12 See, e.g., Marron v. United States, 275 U.S. 192 (1927); Go-Bart Importing Co. v. United States, 282 U.S. 344 (1931); Harris v. United States, 331 U.S. 145 (1947); Way, Increasing Scope of Search Incident to Arrest, 1959 WASH. U.L.Q. 261. 
officers. ${ }^{13}$ Only the last of these issues appears clearly to be resolved at the present time. 14 Typically, since the Second World War, important decisions have commanded only slender majorities. 15 Moreover, substantial changes in Court personnel have not seen positions first announced by such majorities become firmly entrenched. Rather, the gradual change in personnel has led to radical shifts in position, and to bitter complaints produced by "unexpected changes in the Court's composition and the contingencies in the choice of successors." 16

In his article, The Wolf Case: Search and Seizure, Federalism, and the Civil Liberties, ${ }^{17}$ Allen has suggested that this instability is to be explained in part by the difficulty of choosing between two competing values, each of the highest and most obvious importance: the right of privacy and the need for effective law enforcement. "So long," he says, "as the Court feels itself compelled to resolve these issues by choosing one set of social values to the exclusion of the other, any decision must inevitably leave the law in a state of unstable equilibrium."18 But competing values are not unique to search and seizure law. The possibility of conflict appears whenever constitutional limitations are imposed on law enforcement. Still, one is hard-pressed to call to mind areas of equally deep dispute and irresolution.

It is suggested in this article that the conflicts and confusions in search and seizure law have a dual source: first, the difficulty which the Court has experienced in interpreting an ambiguous amendment largely barren of historical gloss; second, and perhaps more important, the failure of the courts to develop a definition of the liberty to be protected which is capable of guiding amendment interpretations by clear social policies. The results, during the first half of this century, were several. (a) The liberty preserved by the amendment came to be called "the right of privacy"-a notion drawn largely from property law. That right, scarcely capable of explaining the full restrictions imposed on law enforcement efforts, nevertheless diverted the Court from an analysis of the broad range of values which often affected its decisions. At the same time, the right of privacy imported into search and seizure anomalous

13 See, e.g., Wolf v. Colorado, 338 U.S. 25 (1949); Rochin v. California, 342 U.S. 165 (1952); Allen, The Wolf Case: Search and Seizure, Federalism, and the Civil Liberties, 45 ILL. L. REv. 1 (1950). It is noteworthy that Allen, in his suggestion that the federal exclusionary rule be extended to the states, anticipated virtually every argument for that position advanced by the Court in Mapp v. Ohio, 367 U.S. 643 (1961).

14 Even the suggestion that fourth and fourteenth amendment requirements are now identical may be open to doubt, inasmuch as it rests upon obiter dicta and implication from the Elkins decision.

15 Out of approximately 30 search and seizure cases decided by the Court during the period, nearly two-thirds were determined by $6-3$ or $5-4$ votes.

16 United States v. Rabinowitz, 339 U.S. 56, 86 (1950) (Frankfurter, J., dissenting).

17 Supra note 13 , at 3 .

18 Id. at 4. 
rigidities derived from private property law. (b) Pressing law enforcement needs were accomodated by an ad hoc expansion of the right of search incident to arrest. But, for all its importance to actual police practice, the doctrine was related to neither the language nor the policies of the amendment until 1950. (c) United States v. Rabinowitz, ${ }^{19}$ by enthroning the rule of reasonableness, made search incident to arrest constitutionally respectable. At the same time, however, the rule cast into bold relief the bankruptcy of clear objectives which has characterized search and seizure decisions.

Mr. Justice Frankfurter has said:

The divisions in this Court over the years regarding what is and what is not to be deemed an unreasonable search within the meaning of the Fourth Amendment and the shifting views of members of the Court in this regard, prove that in evolving the meaning of the Fourth Amendment the decisions of this Court have frequently turned on dialectical niceties and have not reflected those fundamental considerations of civilized conduct on which applications of the Due Process Clause turn.20

It is here suggested that fundamental considerations of civilized conduct have been present in the cases, if not as clearly-defined objectives then as shadows on the fourth amendment. It may be that the understanding of these shadowy determinants at work in search and seizure law is essential to the restoration of communication between the Court and the people whose sensibilities the Constitution must ultimately reflect.

\section{The Right of PrIvacy}

Three recent decisions of the Court"1 have been significant in "factoring out" one of the major interests at work in search and seizure law. When the fourth amendment is said to protect "the right of privacy," what is meant, in part, is the right of undisturbed enjoyment of one's property, the right to shut the door to officers of the state.22 This concept, with roots deep in the private law of property, has had a central influence upon search and seizure law. Pitt appealed to it in his eloquent arguments against the general warrant: "The poorest man may, in his cottage, bid defiance to all the forces of the Crown. It may be frail; its roof may shake; the wind may blow through it; the storm may enter; the rain may enter; but the King of England may not enter; all his force dares not cross the threshold of the ruined tenement." 23 Lord Camden, in Entick v. Carrington, based his classic ruling against the validity of general warrants on the same ground: "The great end, for which

19339 U.S. 56 (1950).

20 Elkins v. United States, 364 U.S. 209, 238-39 (1960) (dissenting opinion).

21 Frank v. Maryland, 359 U.S. 360 (1959); Abel v. United States, 362 U.S. 217 (1960); Ohio ex rel. Eaton v. Price, 364 U.S. 263 (1960).

22 See, e.g., Wolf v. Colorado, 338 U.S. 25, 27-29 (1949); Johnson v. United States, 333 U.S. 10, 14, 17 (1948).

${ }^{23}$ Quoted in Cooley, Constitutional LIMTtaTions 299 n.3 (1868). 
men entered into society, was to secure their property.... By the laws of England, every invasion of private property, be it ever so minute, is a trespass. No man can set his foot upon my ground without my license, but he is liable to an action, even though the damage be nothing." 24 This property-based right of privacy, in addition to lending its name to the whole of the liberty which the fourth amendment is said to safeguard, may be the only civil liberty operating on the amendment which has been clearly articulated by the courts.

Search and seizure cases typically involve searches for evidence of crime. The significance of the recent cases is that the searches there considered were initiated with a view to civil, rather than criminal, proceedings. The interest at stake was, in the eyes of the majority, what might be called the "pure" right of privacy, i.e., the interest violated by the entry and search itself, apart from any consequences which might incidentally result. The difference between the restrictions imposed on these administrative searches, and the restrictions normally imposed on searches for evidence of crime, provides, it is suggested, the measure of the influence which hidden objectives have had on search and seizure law.

In Frank v. Maryland, 25 a city health officer, in response to a complaint regarding the presence of rats in the neighborhood, knocked on the door of appellant's house. Receiving no answer, the officer inspected the area outside the house and found evidence of rodent-infestation. During the course of this inspection the officer was accosted by appellant who asked for an explanation for the officer's presence. The officer responded that he had evidence of unhealthful conditions and requested permission to inspect the basement area. Appellant refused. Later the officer returned, and receiving no response to his knock, swore out a warrant for appellant's arrest, alleging a violation of Section 120 of the Baltimore City Code, which requires that property owners admit health officers for purposes of determining whether suspected nuisances exist.26 On appeal from a subsequent conviction and fine, appellant challenged the validity of section 120 under the fourteenth amendment.

Mr. Justice Frankfurter, speaking for a five-man majority, had little difficulty in finding the provisions of section 120 consistent with due process of law. The right to demand entry, 27 granted to city health officers under the

2419 How. St. Tr. 1029, 1066 (1765).

25 Frank v. Maryland, 359 U.S. 360 (1959). See Note, 108 U. PA. L. Rev. 265 (1959); Comment, 44 Minn. L. Rev. 513 (1960).

26 Art. 12, $\$ 120$ of the Code provides:

"Whenever the Commissioner of Health shall have cause to suspect that a nuisance exists in any house, cellar or enclosure, he may demand entry therein in the day time, and if the owner or occupier shall refuse to delay to open the same and admit a free examination, he shall forfeit and pay for every such refusal the sum of Twenty Dollars." 359 U.S. at 361 .

27 The majority interpreted the statute as giving no right of forceful entry. 359 U.S. at 366-67. For criticism of this construction, see Waters, Rights of Entry of Administrative Officers, 27 U. CHI. L. REv. 79 (1959). 
ordinance, was to be "assessed in the light of the needs which ... produced it."28 The "slight" invasions of privacy permitted were to be weighed against the substantial interests of the community in seeing that hazards to public health were eliminated. Appellant's resistance was characterized as being based "on a rarely-voiced denial of any official justification for seeking to enter his home. The constitutional 'liberty' that is asserted is the absolute right to refuse consent for an inspection designed and pursued solely for the protection of the community's health, even when the inspection is conducted with due regard for every convenience of time and place."29

The majority opinion would have been less striking had it merely defined fourteenth amendment protections against state intrusions upon privacy. ${ }^{30}$ But the majority was prepared to make an $a$ fortiori argument for the constitutionality of section 120 based on standards of the fourth amendment. 31 A vigorous dissent was filed by Mr. Justice Douglas, joined by the Chief Justice, and Justices Black and Brennan. ${ }^{32}$ The broad rights granted under the Baltimore ordinance conformed to none of the standards formerly applied to searches and seizures. No warrant was required, nor were searches to be made incident to criminal arrest. The demand for entry was justified by mere suspicion rather than probable cause. "The decision today," said Mr. Justice Douglas, "greatly dilutes the right of privacy.... We witness today an inquest over a substantial part of the Fourth Amendment." 33

The belief that the Frank opinion could not be dismissed as interpretative of only the fourteenth amendment gained support in Abel v. United States, ${ }^{34}$ decided by the Court in 1960 . There, agents of the Federal Bureau of Investigation suspected appellant of being an espionage agent of the Soviet Union. Despite intensive investigation and surveillance of the suspect, the Justice Department determined that its evidence was insufficient to arrest and convict

${ }^{28}$ Frank v. Maryland, 359 U.S. 360, 367 (1959).

29 Id. at 366.

30 The significance for Mr. Justice Frankfurter of the fact that a search and seizure case arises under the fourteenth, rather than the fourth amendment, must not be underestimated. See Wolf v. Colorado, 338 U.S. 25 (1949); Elkins v. United States, 364 U.S. 206, 233 (1960) (dissenting opinion); Stefanelli v. Minard, 342 U.S. 117 (1951).

31 In Wolf v. Colorado, 338 U.S. 25, 27-28 (1949), Mr. Justice Frankfurter, speaking for the Court, said that "the security of one's privacy against arbitrary intrusion by the police-which is at the core of the Fourth Amendment-is basic to a free society. It is therefore implicit in 'the concept of ordered liberty' and as such enforceable against the States through the Due Process Clause."IIt would appear to be the case that a search violative of ordered liberty would, if conducted by federal officers, violate the fourth amendment requirement of reasonableness. Therefore, searches not violative of fourth amendment protections will a fortiori not violate the fourteenth amendment's protections of the right of privacy.

32359 U.S. at 374.

$33 \mathrm{Id}$. at 374.

34362 U.S. 217 (1960). See Note, 107 U. PA. L. Rev. 1192 (1959); Comment, 34 N.Y.U.L. Rev. 159 (1959); Note, 74 HARV. L. REv. 81, 154 (1960). 
Abel on charges of espionage. Thereupon, the evidence, which indicated that petitioner was an alien residing illegally in this country, was turned over to the Immigration and Naturalization Service, for possible use in deportation proceedings. The INS agents, having secured an "administrative arrest warrant" from the Acting District Director of INS, went, together with FBI agents, to Abel's hotel room. There, the INS officers placed petitioner under formal arrest, and conducted an intensive search of the room and of petitioner's belongings. A further search of the hotel room was made by FBI agents after Abel had been removed. Evidence from these searches formed the basis for a criminal indictment and conviction on the charge of espionage.

On appeal, the administrative arrest was not subject to direct attack; its validity had been conceded by petitioner below. Before the Court, however, was the question of whether such an arrest gave rise to an incidental right of search and seizure. The administrative warrant employed had been issued by an officer of the arresting agency, rather than by an independent magistrate. The statute authorizing the arrest did not require a showing of probable cause, 35 nor did the Court inquire whether probable cause had been, or could have been demonstrated. 36

The minority argued, under these circumstances, that no analogy could be drawn to the right of search incident to criminal arrest, whether with or without a warrant. The over-all protections given to the individual were not equivalent in the two procedures. In the case of criminal arrest and incidental search, it was claimed, the existence of probable cause would be determined by a judicial officer either prior to the arrest, if a warrant were employed, or following the search when the arrestee was brought, as required by law, before a magistrate. 37 In the case of the administrative arrest, on the other hand, probable cause, if present at all, was determined by an officer of the arresting agency; and the agency was under no obligation to bring the arrestee before the courts for a review of that determination. 38

35 Section 242 (a) of the Immigration and Nationality Act of 1952 provides that "Pending a determination of deportability in the case of any alien ... such alien may, upon warrant of the Attorney General, be arrested and taken into custody." 66 Stat. 208, 8 U.S.C. § 1252 (a) (1958). The regulations under the act delegate the authority to issue these administrative warrants to the District Directors of the INS "[a]t the commencement of any proceeding [to deport] ... or at any time thereafter ... whenever, in [their] ... discretion, it appears that the arrest of the respondent is necessary or desirable." 8 CFR $\S 242.2$ (a) (1958). The "Operating Instructions" of the INS direct that "an application to commence proceedings to deport should be based upon a showing of a prima facia case of deportability." 362 U.S. at 232 (emphasis added).

36 Although the validity of the administrative arrest did not depend upon a showing of probable cause, the minority argued that the attachment of a right of incidental search should depend upon such a showing. 362 U.S. at 252-53.

37 See FED. R. CRIM. P. 4, 5, 41. But see Giordenello v. United States, 357 U.S. 480 (1958).

38 Neither $\S 242$ (a) of the Immigration and Nationality Act of 1952, nor the regulations thereunder, impose any limitation on the authority of INS officers to issue arrest warrants 
Mr. Justice Frankfurter, speaking for the majority, questioned the alleged disparity of protections, but argued, as in Frank, that the fourth amendment does not impose the same standards upon administrative searches as upon searches for evidence of crime. ${ }^{39}$ Assuming good faith on the part of the arresting officers, only the fourth amendment's protection of the right of privacy was involved; that interest was clearly outweighed by the interests of society in the deportation of a suspected alien. Abel may be said to have further narrowed the protections which the Frank case had accorded the right of privacy. In Abel the Court could no longer say that the search in question was "designed to make the least possible demand on the individual occupant, and to cause only the slightest restriction on his claims of privacy." 40 Indeed the invasions were perhaps as great as the Court had ever before considered in a fourth amendment case. 41

The view of the majority toward probable cause to justify an administrative search may be seen in Ohio ex rel. Eaton v. Price 42 decided the same Term. The facts were similar to those in Frank v. Maryland. In Price, however, city inspectors demanded entry to petitioner's home without any grounds to believe, so far as the record reveals, that proscribed conditions existed within. Furthermore, the record does not indicate that the demanded inspection was made in pursuance of a routine spot check of individual homes. Four members of the Frank and Abel majorities ${ }^{43}$ voted against noting probable

after the commencement of deportation proceedings; the "Operating Instructions" of the INS merely state that in commencing such proceedings-which are wholly administrative rather than judicial in nature-there "should" be a showing of a "prima facia case" of deportability. See note 35 supra.

Under the act all determinations of the Attorney General-whether concerning detention, release on bond, parole, or deportation-are final and conclusive, with one exception. $\$ 1252$ (a) provides: "Any court of competent jurisdiction shall have authority to review or revise any determination... concerning detention, release on bond, or parole pending final decision of deportability upon a conclusive showing in habeas corpus proceedings that the Attorney General is not proceeding with such reasonable dispatch as may be warranted. ..." 66 Stat. 208, U.S.C. \$1252 (a) (1958) (emphasis added).

39 "The differences between the procedural protections governing criminal and deportation arrests are not of a quality or magnitude to warrant the deduction of a constitutional difference regarding the right of incidental search. If anything, we ought to be more vigilant, not less, to protect individuals and their property from warrantless searches made for the purpose of turning up proof to convict than we are to protect them from searches for matter bearing on deportability. According to the uniform decisions of this Court, deportation proceedings are not subject to the constitutional safeguards for criminal prosecutions. Searches for evidence of crime present situations demanding the greatest, not the least, restraint upon the government's intrusion into privacy; although its protection is not limited to them, it was at these searches which the Fourth Amendment was primarily directed." 362 U.S. at 237.

40 Frank v. Maryland, 359 U.S. 360, 367 (1959).

41 See Abel v. United States, 362 U.S. 217, 223-25, 251 (1960); Record, pp. 22-32, 58-62.

42364 U.S. 263 (1960). See Note, 59 Mrch. L. Rev. 447 (1961).

43 Justices Frankfurter, Clark, Harlan and Whittaker. Mr. Justice Stewart, the fifth member of the Frank and Abel majorities, took no part in the consideration of the case. 
jurisdiction, indicating in a special memorandum ${ }^{44}$ that they considered the Frank decision "completely controlling." The judgment upholding the inspection ordinance was affirmed by an equally-divided Court. 45

The conclusion to be drawn from these recent cases is that when a search is not made for evidence of crime, or does not otherwise threathen "further deprivations of life, liberty, or property," only the right of privacy is said to be at stake. This interest does not require and could not justify, in the eyes of the Court, the full protection which customary restrictions on search and seizure provide. Customary restrictions on searches for evidence of crime must find their justification in additional civil liberties capable of balancing the necessities of law enforcement. 46 The administrative search cases demonstrate a failure of the Court to identify these additional interests.

The distinction which the Court sought was not, of course, self-evident. In a case similar to Frank, Judge Prettyman had concluded that "to say that a man suspected of crime has a right to protection against search of his home without a warrant, but that a man not suspected of crime has no such protection, is a fantastic absurdity." 47 The rebuttal upon which the Supreme Court was to rest was found in a peculiarly opaque passage from Frank:

[T]wo protections emerge from the broad constitutional proscription of official invasion. The first of these is the right to be secure from intrusion into personal privacy, the right to shut the door on officials of the state unless their entry is under proper authority of law. The second, and intimately related protection, is selfprotection: the right to resist unauthorized entry which has as its design the securing of information to fortify the coercive power of the state against the individual, information which may be used to effect a further deprivation of life or liberty or property. Thus, evidence of criminal action may not, save in very limited and closely confined situations, be seized without a judicial warrant. . . . [H]istory makes plain

44360 U.S. 264 (1959). Both the special memorandum and the dissenting opinion following affirmance by an equally-divided Court are unusual. Ordinarily, the judgment of any four justices on the question of noting probable jurisdiction is accepted without indication of dissent. Application for review of Price, however, came before the Court within two weeks of the Frank opinion. In the view of the Justices opposed to noting probable jurisdiction, the cases involved exactly the same constitutional questions. "The result, for all practical purposes," said Mr. Justice Clark, "is a reconsideration of the constitutional question decided in Frank by a full Court. This flies in the face of the real purpose ... of our Rule 58 which permits rehearing only 'at the instance of a justice who concurred in the judgment or decision. ..." "' 360 U.S. at 249.

4s Ohio ex rel Eaton v. Price, 364 U.S. 263 (1960).

46 Absent Abel, the problem might not have arisen. Administrative searches could have been distinguished from criminal searches, and a difference in safeguards justified, in terms of the degree of harm normally involved; the constitutional interests at stake might have been the same. Abel showed, however, that administrative searches are not limited to basements and rubbish bins. Qualitative, not quantitative differences in harm were demanded if the distinction was to survive.

47 District of Columbia v. Little, 178 F.2d 13, 17 (D.C. Cir. 1949). 
that it was on the issue of the right to be secure from searches for evidence to be used in criminal prosecutions or for forfeitures that the great battle for fundamental liberty was fought. 48

Only the first of these two rights was involved in administrative searches. Both were threatened in searches for evidence of crime.

A distinction based on the subsequent harms which may result from a search is a tempting one. The quoted passage may suggest that the more serious the threat of injury which a search poses, the greater the justification which should be demanded for the search. Thus, searches for evidence of crime, posing the threat of subsequent conviction and criminal sanctions, should be surrounded with greater safeguards than are administrative searches. In this notion may lie an elementary but pervasive error in fourth amendment theory. Searches for evidence of crime may be required to secure criminal convictions; the justification for the search, however, cannot and need not justify the resulting conviction. The conviction and its results are independently justified by the fact of the crime, evidence of which the search has uncovered. 49

No conflict arises with an argument, properly employed in support of the exclusionary rule, 50 that the state should not benefit from the illegal behavior of its officers, that illegally secured evidence should not form the basis for a criminal conviction. That argument, when applied to the present issue, however, begs the very question to be answered: what standards shall be imposed on searches and seizures?

Thus, whatever "history makes plain"s1 and whatever may be meant by

\section{U.S. at 365.}

49 A partial explanation for confusion on this point may lie in misunderstandings of the exclusionary rule which renders inadmissable evidence secured through illegal or "unjustified" search and seizure. It might be concluded that the rule assumes that such convictions would themselves be unjustified. Such a position would properly be subject to Wigmore's charge of "sentimentality" toward offenders, (8 WIGMORE, EVIDENCE § 2184 (3d ed. 1940)) or to Cardozo's characterization: "The criminal is to go free because the constable has blundered." (People v. Defore, 242 N.Y. 13, 21, 150 N.E. 585, 587 (1926).)

Arguably, neither the exclusionary rule nor the fourth amendment which it was designed to enforce has as its purpose the protection of any but the innocent. So long as guilt or innocence is undetermined, however, restrictions must be imposed on all searches and seizures. To enforce those restrictions, the exclusionary rule merely deprives officers, who have conducted unjustified, but successful, searches of the fruits of their unlawful behavior.

50 See, e.g., Allen, supra note 13, at 20.

51 In the passage quoted from Frank, Mr. Justice Frankfurter may virtually have conceded that history lends only inconclusive support to the proposed distinction between restrictions on criminal and administrative searches. One of the cases upon which he relied, Boyd v. United States, 116 U.S. 616 (1886), involved the compulsory production of documents in a forfeiture proceeding. Criminal penalties were not at issue. Similarly, the colonial writs of assistance, against which the fourth amendment was directed, were often employed merely to find and seize smuggled goods subject to forfeiture. See generally LASSON, HrsTORY and Development of tHe Fourth AMENDMENT to the United States Constitumion 51-78 (1937). The purpose for seeking information in these circumstances was admittedly 
"the right of self-protection," introduced for the first time in Frank, this much is clear. The subsequent disadvantages to the individual which may result from a search for evidence of crime cannot support the distinction in protections upon which the recent administrative cases rest. The distinction must be justified, if at all, by the full range of interests which bear upon the operation of the fourth amendment.

\section{Private Law and the Conceptual Framework}

Whatever may be said of the treatment which the proprietary interes7 at stake in the Frank case recieved at the hand of Mr. Justice Frankfurter, it is clear that the common law of torts and property, in which such an interest has its roots, has had a pervasive influence on the law of search and seizure. Indeed, the conceptual framework within which the fourth amendment has developed is a private law framework designed to secure undisturbed enjoyment of private property. 52 Only a few examples are necessary to recall the almost total reliance of the fourth amendment's legal history on this conceptual scheme.

1. For a search to come within the contemplation of the amendment, it must involve a physical trespass on a protected space. 53 The analogy is not perfect, for the amendment does not prohibit searches in open fields even if entry is trespassory. ${ }^{54}$ This is only to say, however, that the spaces protected by the amendment form a proper part of the more inclusive areas protected by property law.

2. The remedy for unconstitutional search and seizure by federal officers was, until 1914,55 the common law action in trespass. Until Mapp, this continued to be the basic remedy for violation of provisions against unreasonable search and seizure in nearly half the states. 56 However unlawful the entry, however thorough the search, or whatever the consequences in terms of embarrassment, notoriety or even criminal prosecution, the remedy was basically the same as the property owner would have had against an intruding neighbor. 57

\footnotetext{
"to fortify the coercive power of the state against the individual." But the recent cases are not clearly distinguishable on these grounds. In Frank and Price, the attempted searches, if successful, were to result in the compulsory abatement of discovered nuisances. In Abel, compulsory deportation was envisioned. In all three cases, some subsequent, if not immediate, limitations upon the rights of life, liberty or property were threatened.

52 See, e.g., Entick v. Carrington, 19 How. St. Tr. 1029, 1066 (1765); Jones v. United States, 362 U.S. 247, 261 (1960). Also see generally Barrett, supra note 11.

53 MaGumRe, Evidence of GuIt 188 (1959). See Goldman v. United States, 316 U.S. 129 (1942). Compare Silverman v. United States, 365 U.S. 505, 512 (1961).

54 Hester v. United States, 265 U.S. 57, 59 (1924).

55 See Weeks v. United States, 232 U.S. 383 (1914).

56 See Elkins v. United States 364 U.S. 206, 224 (1960) (Appendix, Table D).

57 Cf. Note, 32 W. VA. L.Q. 68 (1925). But see 18 U.S.C. $\$ 2236$ (1950).
} 
3. In the event of an unlawful seizure, the offended party is directed to move in the courts for the return of his property58 -an action not unlike that of replevin.

4. Not everyone detrimentally affected by an unconstitutional search and seizure has standing to secure a remedy, even where that remedy is in the form of a suppression of evidence secured through illegal search. Until the recent decision in Jones $v$. United States, 59 courts of appeals had generally required that the movant claim either to have owned or possessed the seized property or to have had a substantial possessory interest in the premises searched. The possessory interest was required to be greater than that of an "invitee" or "guest." 60 The Court in Jones granted standing to move for suppression of evidence "to "anyone legitimately on premises where a search occurs."61

5. The Court's difficulty in dealing with modern electronic methods of eavesdropping, where no physical trespass on private property is involved, reflects a conceptual framework drawn from the law of property. In Goldman v. United States, ${ }^{62}$ officers overheard defendant's conversations in an adjoining office by means of a delicate microphone placed against a common wall. The officer's testimony concerning the conversations was held by the Court to be admissible into evidence on the ground that no physical trespass was involved. In Silverman v. United States ${ }^{63}$ police officers accomplished the same objective by driving a "spike microphone" several inches into a party wall. The Court declined to overrule Goldman, yet refused to go beyond it "by even a fraction of an inch." "Decision here does not turn upon the technicality of a trespass upon a party wall as a matter of local law," claimed Mr. Justice Stewart for the unanimous Court. "It is based upon the reality of an actual intrusion into a constitutionally protected area." 64 But the fraction of an inch was decisive and the evidence secured by the spike microphone held inadmissable.

6. Restrictions on "seizables," even when found in the course of a lawful search, bear the same marks. In Gouled v. United States, the Court stated that even pursuant to a warrant, search and seizure "may be resorted to only when a primary right to such search and seizure may be found in the interest which the public or the complainant may have in the property to be

58 See Segurolo v. United States, 275 U.S. 106 (1927).

59362 U.S. 257 (1960).

60 Id. at 265, 266. See United States v. Jeffers, 342 U.S. 48 (1951).

61362 U.S. at 367.

62316 U.S. 129 (1942). See also Olmstead v. United States, 277 U.S. 438 (1928); On Lee v. United States, 343 U.S. 747 (1952).

63365 U.S. 505 (1961).

$64 \mathrm{Id}$. at 512. 
seized, or in the right to the possession of it, or when a valid exercise of the police power renders possession of the property by the accused unlawful and provides that it may be taken." 65 Thus, there emerged in the cases an exclusive list of categories of property which might be the object of lawful search and seizure. The categories include contraband ${ }^{66}$ (the unauthorized possession of which is illegal), stolen property67 (the rightful owner being entitled to possession), excisable or dutiable articles ${ }^{68}$ (the government having a lien-type interest to insure payment of duties thereon), and instrumentalities of crime69 (the owner having abused state-granted property rights, thereby subjecting the chattels to governmental seizure, the purpose of which is the suppression of a nuisance). It may be that this property-based theory of seizables best explains the long-standing rule of the Court forbidding the seizure of "merely evidentiary articles." 70 To say that objects have merely evidentiary importance may be to say that no defect in title or possessory interest legitimizes their seizure from a rightful owner. 71

The pervasive influence of the conceptual framework of private property law may explain the tendency of the courts to speak as if the right of privacy were the only civil liberty protected by the fourth amendment. But it is interesting to note that the law of property does not itself support the high rigid standards which have traditionally been imposed on searches for evidence of crime. If the fourth amendment requires only that personal privacy be balanced against the need of society for law enforcement, the substantive standards of property law should be reflected in the constitutional standard of reasonableness for search and seizure; the constitutional standard of reasonableness would never be more restrictive than is the law of property itself.

The right to freedom from trespassory incursions on private property was never absolute at common law. Both entries upon land and interferences with personal property were permitted when public necessity required.72 Indeed, even private "necessity" justified invasions of property which would otherwise be trespassory. ${ }^{73}$ The degree of public or private need required,

65255 U.S. 298, 309 (1921).

66 See Harris v. United States, 331 U.S. 145, 154-55 (1947).

67 See Boyd v. United States, 116 U.S. 616, 623-24 (1886).

68 Ibid.

69 See Marron v. United States, 275 U.S. 192 (1927).

${ }^{70}$ See Boyd v. United States, 116 U.S. 616 (1886); Davis v. United States, 328 U.S. 582, 587 (1949); Comment, Limitations on Seizure of "Evidentiary" Objects, a Rule in Search of a Reason, 20 U. CHr. L. Rev. 319 (1953).

71 But see pp. 692-98 infra.

72 See Prosser, ToRTs $96 \mathrm{nn.71-76} \mathrm{(2d} \mathrm{ed.} \mathrm{1955)} \mathrm{and} \mathrm{cases} \mathrm{cited} \mathrm{therein.}$

73 See Ploof v. Putnam, 81 Vt. 471, 71 Atl. 188 (1908). Compare Vincent v. Lake Erie Transp. Co., 109 Minn. 456, 124 N.W. 221 (1910). See generally ProsseR, op. cit. supra note 72 , at 97-98 nn.77-83. 
however, has varied from period to period. ${ }^{74}$ In describing the Frank decision as "an inquest over a substantial part of the fourth amendment," the minority may have reflected the view that the amendment had elevated eighteenth century property rights to the level of a constitutional liberty. ${ }^{75}$ Well it may be that the search for rats and rubbish was insufficient in the eighteenth century to justify an entry of the King into the ruined tenement. Since the enactment of the amendment, however, the law's reverence for private property has diminished substantially with the ever-increasing complexity of urban society. It is not clear that the rights granted health officers in Baltimore were substantially greater than those possessed by a private citizen acting to abate a nuisance. 76

If the amendment did not ossify the substantive protections of property during any given period, it may well be said to have extended against officers of the state whatever restrictions would be imposed by an evolving law of property. And if this notion were to be reflected in constitutional standards of reasonable search and seizure, the result might well be a calculus, rather than a body of rules defining reasonableness. The determinants of the calculus would include those factors considered by Mr. Justice Frankfurter in Frank v. Maryland: the seriousness of the invasion of privacy involved, the probability that the search would uncover the offending objects sought, and the public need by which the invasion was sought to be justified.77 By operation of such a calculus, the detection of minor crimes might legitimize only minor invasions of privacy. Virtual certainty of success, by objective standards, would justify greater invasions than could be countenanced on the basis of less adequate information. The necessity of resolving or preventing a particularly heinous crime might justify minor invasions on the liberty of many individuals, even where the probability of success in any given case was low.

Although such a calculus may comport with untutored views of reasonableness, no such approach emerged from the history of fourth amendment litigation in the Supreme Court until the recent cases of administrative search. Before that time, only Mr. Justice Jackson had ever given any indication that such a calculus might be appropriate to the analysis of search and seizure problems generally. It was he who in a dissenting opinion in Brinegar v. United States said:

But if we are to make judicial exceptions to the Fourth Amendment for these reasons, it seems to me they should depend somewhat upon the gravity of the offense.

74 See Ploof v. Putnam, 81 Vt. 471, 71 Atl. 188 (1908) and cases cited therein.

75 For Mr. Justice Douglas, if not for those who joined him, it must be said that the fourth amendment, if it encompasses these property notions, is not limited by them. See On Lee v. United States, 364 U.S. 505, 512 (1961) (concurring opinion).

${ }^{76}$ See Jones v. Williams, 152 Eng. Rep. 764 (1843); Maryland Tel. \& Tel. Co. v. Ruth, 106 Md. 644, 68 Atl. 358 (1907); Hubbard v. Preston, 90 Mich. 221, 51 N.W. 209 (1892); see Prosser, op. cit. supra note 72, at 419-21 and cases cited therein.

77359 U.S. at $366,371$. 
If we assume, for example, that a child is kidnapped and the officers throw a road block about the neighborhood and search every outgoing car, it would be a drastic and indiscriminating use of the search. The officers might be unable to show probable cause for searching any particular car. However, $I$ should candidly strive hard to sustain such an action, executed fairly and in good faith, because it might be reasonable to subject travelers to that indignity if it was the only way to save a threatened life and detect a vicious crime. But I should not strain to sustain such a roadblock and universal search to salvage a few bottles of bourbon and catch a bootlegger. 78

The beginning of wisdom in search and seizure law may lie in asking why it is that the calculus recently applied in Frank has not emerged from the much longer history of cases involving searches for evidence of crime.

\section{INTERPRETATIONS OF THE FOURTH AMENDMENT: THE SEARCH FOR THE MisSING CONNECTIVE}

The inflexibilities in traditional standards of search and seizure may be traced, in large measure, to the language of the fourth amendment itself: "The right of the people to be secure in their persons, houses, papers, and effects, against unreasonable searches and seizures, shall not be violated, and no warrants shall issue, but upon probable cause, supported by Oath or affirmation, and particularly describing the place to be searched, and the persons or things to be seized."79

Much of the conflict which centers around these words concerns the proper relationship between the reasonableness and warrant clauses. ${ }^{80}$ In vacuo, the language might be read as establishing a general requirement of reasonableness for all searches and seizures, while commanding that if a warrant be the authority for a search, it comply with certain formal requirements. History, however, lends little support to such a reading.

The practice which precipitated the amendment was the use of general warrants and writs of assistance by His Majesty's officers to enforce unpopular taxation schemes. ${ }^{81}$ The concomitant period in England saw the same devices fall into ill-repute when employed in the suppression of political dissent. In 1763, the courts of England declared general warrants illegal.82

That the framers of the amendment had as their primary, if not sole, purpose the prohibition of general warrants is strikingly demonstrated in the records of the first Congress. On August 17, 1789, the House of Representa-

78338 U.S. 160, 183 (1949).

79 U.S. CoNsT. amend. IV.

80 See generally Lasson, History and Development of the Fourth Amendment TO THE UNITED STATES CONSTITUTION 13-105 (1937); Reynard, Freedom from Unreasonable Search and Seizure-A Second Class Constitutional Right ? 25 IND. L.J. 259, 262-77 (1950).

81 See LASSON, op. cit. supra note 80, at 51-78.

82 Huckle v. Money, 95 Eng. Rep. 768 (1763); Wilkes v. Wood, 19 How. St. Tr. 1153 (1763). See also Entick v. Carrington, 19 How. St. Tr. 1029 (1765). 
tives, sitting as a Committee of the Whole, debated a proposed draft of the amendment. The draft read: "The right of the people to be secured in their persons, houses, papers, and effects, shall not be violated by warrants issuing without probable cause, supported by oath or affirmation, and not particularly describing the place to be searched, and the persons or things to be seized." 83

The full debate on the draft is reported in a few paragraphs of the Annals. Two amendments to the clause were proposed: "Mr. Gerry said he presumed there was a mistake in the wording of this clause; it ought to be 'the right of the people to be secure in their persons, houses, papers, and effects, against unreasonable seizures and searches,' and therefore moved that amendment." 84 The motion passed. The more crucial amendment to the proposed draft was made by Benson: "Mr. Benson objected to the words "by warrants issuing.' This declaratory provision was good as far as it went, but he thought it was not sufficient; he therefore proposed to alter it so as to read 'and no warrant shall issue." The report continues: "The question was put on this motion and lost by a considerable majority." 85

When the committee appointed to arrange the articles of amendment, under the chairmanship of Mr. Benson, reported to the House on August 24, however, the fourth was worded in its present form. The change apparently went unnoticed and the amendments were approved as reported. ${ }^{86}$ Senate debates on the amendments were held in secret session, and no unofficial report of discussion on the fourth is available. 87 There was, thus, no indication that anything more was intended by the fourth amendment than the establishment of a warrant vehicle for official searches. The reasonableness clause was barren of historical content.

The subsequent history of fourth amendment cases may be described as a struggle between two interpretations. Otherwise described, it was a search for a connective which would make clear the logical relationship of the amendment's two clauses. The first construction was not clearly articulated by the Court until after the Second World War. Arguably, however, it was the premise upon which all prior cases had rested. ${ }^{88}$ The principle was stated by Mr. Justice Jackson in Johnson v. United States:

The point of the Fourth Amendment, which often is not grasped by zealous officers, is not that it denies law enforcement the support of usual inferences which

83 AnNals OF Cong. 783 (1789).

${ }^{84} \mathrm{Ibid}$.

85 Ibid.

86 Id. at 808-09; House Journal, Aug. 24, 1789.

87 See LAsson, op. cit. supra note 80 , at $102 \mathrm{n} .86$.

88 Early commentators read the amendment to require warrants for all searches, with narrow exceptions, and, in addition, to demand that warranted searches be conducted reasonably. See, e.g., Cooley, Constitutional Limitations 299-308 (1868); Black, CONSTITUTIONAL LAW 435-42 (1895). 
reasonable men draw from evidence. Its protection consists in requiring that those inferences be drawn by a neutral and detached magistrate instead of being judged by the officer engaged in the often competitive enterprise of ferreting out crime.... When the right of privacy must reasonably yield to the right of search is, as a rule, to be decided by a judicial officer, not by a policeman or government enforcement agent. 89

The same term, Mr. Justice Murphy, speaking for the Court in Trupiano v. United States, was even more specific in saying: "it is a cardinal rule that, in seizing goods and articles, law enforcement agents must secure and use search warrants wherever reasonably practicable."90 The rule was straightforward, the relationship between the clauses of the amendment clear: save for narrow exceptions arising from emergency circumstances, a valid warrant was "a sine qua non of the reasonableness of a search."91

The striking rigor of the Trupiano rule lies in the amendment's warrant requirements themselves. Warrants were to issue only upon a showing of probable cause. The rule was interpreted to require a uniform quantum of pre-search information for every search and seizure.92 However great or slight the invasion, or however pressing the community interest at stake, the threshold level of information required was the same. 93 Two further requirements on the issuance of search warrants are significant. The probable cause which justifies a warrant was to be "supported by Oath or affirmation." Until some years after Trupiano, this requirement was interpreted to demand that affiants declare only first hand information. "Hearsay evidence" could not constitute probable cause. ${ }^{94}$ The amendment further required that the persons or things to be seized be particularly described in the warrant. Consequently, officers could not seize evidence which unexpectedly came to their attention during the course of a warranted search.95

89333 U.S. 10, 13-14 (1948).

90334 U.S. 699, 705 (1948).

91 Cf. United States v. Rabinowitz, 339 U.S. 56, 65 (1950).

92 See, e.g., Dumbra v. United States, 268 U.S. 435 (1925); Steele v. United States [No. 1], 267 U.S. 498 (1925); United States v. Clancy, 276 F.2d 617 (7th Cir. 1960).

${ }_{93} \mathrm{An}$ alternative interpretation of the probable cause requirement may have been left open to the Court by the wording of the amendment. "Probable cause" might be interpreted "probable cause to issue." Included in the notion would be all the considerations relevant to the proper issuance of the writ. See text accompanying notes 213-16 infra. Read in this manner, the provision would itself embody the general requirement of reasonableness or appropriateness. The construction chosen by the Court, on the other hand, clearly reads "probable cause" to mean "probable cause to believe that seizable objects will be found in the place to be searched." The latter test is, in form, a factual one, once the required level of probability is set. The former test may require a complex of valuational judgments in addition to determining whether sought objects will be found.

${ }_{94}$ See Director General v. Kastenbaum, 263 U.S. 25 (1923); Poldo v. United States. 55 F.2d 866, 869 (9th Cir. 1932). For the present rule see Draper v. United States, 358 U.S. 307 (1959); Jones v. United States, 362 U.S. 257 (1960).

95 See, e.g., Marron v. United States, 275 U.S. 192 (1927). But see note 141 infra. 
The continual resistance of law enforcement agencies to these restrictions was to be expected. The reason for the requirement of personal knowledge of affiants was clear. Yet customary and perhaps essential techniques for acquiring information of crime were thwarted. In many circumstances, the police were dependent upon informers and under-cover agents. But informers often refused to sign their names to public affidavits for fear of reprisals, and under-cover agents hesitated to do the same for fear of losing their future effectiveness. 96 The greatest resistance of police to restrictions on search developed during the period of national prohibition. With the widespread growth of new "victimless crimes," law enforcement agents became especially dependent upon search as an investigative technique. Without a complaining witness, however, the police found it difficult to anticipate and to establish with probable cause, what objects would be found employed in a criminal enterprise. The problem often arose even when officers had reasonable grounds to believe that a given individual had committed an offense. 97

The second basic interpretation of the amendment appeared only two years after Trupiano. 98 Mr. Justice Minton, speaking for a new majority in United States $v$. Rabinowitz stated:

A rule of thumb requiring that a search warrant always be procured whenever practicable may be appealing from the vantage point of easy administration. But we cannot agree that this requirement should be crystallized into a sine qua non of the reasonableness of a search.... The relevant test is not whether it is reasonable to procure a search warrant, but whether the search was reasonable. 99

In a sharply worded dissent, Mr. Justice Frankfurter retorted:

There must be a warrant to permit search, barring only inherent limitations upon that requirement when there is a good excuse for not getting a search warrant.... It is not a rule of thumb. It is a rule of the Fourth Amendment and of the reasons for its adoption. It is not a rule invented in Trupiano v. United States.... It is not a rule of those who came on this Court in recent years. ...100

$96 \mathrm{Mr}$. Virgil Peterson, Operating Director of the Chicago Crime Commission, and former FBI agent, has argued this point in Law and Police Practice: Restrictions in the Law of Search and Seizure, 52 Nw. U.L. Rev. 46, 57 (1957).

97 For a reference to widespread police resistence, see National COMM'N ON LAW OBSERVANCE AND ENFORCEMENT, ENFORCEMENT OF THE PROHIBITION LAWS OF THE UNITED States 66 (1931); see generally NATIONAL. COMm'N ON LAW OBSERVANCE AND ENFORCEMENT, REPORT ON LAWLESSNESS IN LAW ENFORCEMENT (1931). A modern police assessment of the difficulties in operating under search warrants may be found in Affidavit of William H. Parker, Chief of Police of the City of Los Angeles, Appendix " $D$ " to petition to appear as Amicus Curiae and the Brief in Support of Respondent's petitions for Rehearing in People v. Cahan, 44 Cal. App. 461, 232 P.2d 905 (1955).

${ }^{98}$ The death of Justices Rutledge and Murphy, members of the Trupiano majority, had brought Justices Clark and Minton to the Court.

99239 U.S. 56, 65-66 (1950). With Mr. Justice Minton in the majority were the Chief Justice, Justices Clark, Burton, and Reed. Dissenting were Justices Black, Jackson, and Frankfurter. Mr. Justice Douglas took no part in the consideration of the case.

100339 U.S. at 83-84. 
The "unexpected changes in the Court's composition," of which Mr. Justice Frankfurter complained in his dissent, 101 however, could not fully explain the radical shift in theory. The overruling of Trupiano was not a random or capricious act. If Trupiano was the clearest articulation of a rule upon which prior cases had rested, it nonetheless stated a rule which already had been undermined by exceptions.

The first of these exceptions to traditional warrant requirements was the right to search moving vehicles, established in Carroll $v$. United States. ${ }^{102}$ The second, and far more important, was the right of search incident to arrest. ${ }^{103}$ Either exception might have been justified by reference to the requirement of reasonableness. Moving vehicles could escape the jurisdiction before officers had time to secure a warrant ${ }^{104}$ and without the right to deprive offenders of weapons and other means of escape, officers could not safely make arrests. ${ }^{105}$ But traditional constructions of the amendment, as summarized in the rule of Trupiano, had not left the meaning of the reasonableness

\section{Id. at 86.}

102267 U.S. 132 (1925). The search was made under authority of $\S 26$, Title II of the National Prohibition Act, 41 Stat. 305, 315 (1919) which imposed on officers the duty of seizing intoxicating liquor transported contrary to law. In arguing that Congress did not intend that a warrant was to be required under this section, the Court pointed to a supplemental act which made searches of private dwellings without a warrant a misdemeanor. 42 Stat. 222, 223 (1921). The Court observed that the Stanley Amendment to the latter act, which would have made all warrantless searches for liquor illegal, was defeated by Congress. The House Judiciary Committee had objected to the amendment, in part, because "it will make it impossible to stop the rum running automobiles engaged in a like illegal traffic." 267 U.S. at 143-47. The Court also supported its ruling by reference to an act of the first Congress which authorized customs officers to search "any ship or vessel, in which they shall have reason to suspect any goods ... . subject to duty shall be concealed." Id. at 150 . The same act provided that a search warrant should be secured to enter any house or other buiding to look for dutiable goods. Act of July 31, 1789, Sec. 24, 1 Stat. 29.

103 See 1 Bishop, CRIMINAL ProcedURe 116-18 (3d ed. 1880). "The right goes back beyond doubt to the days of the hue and cry, when there was short shrift for the thief who was caught 'with the mainour,' still 'in seisin of his crime'." People v. Chiagles, 237 N.Y. 193, 196, 142 N.E. 583, 584 (1923) and cases cited therein. An offender, "overtaken by hue and cry while he has still about him the signs of his crime, ... will be bound, and if we suppose him a thief, the stolen goods will be bound on his back." PollacK \& MarrLAND, 2 HISTORY OF ENGLISH LAW 579 (2d ed. 1899). Concerning early recognition of the right to search an arrestee for fruits and instrumentalities of crime see BISHOP, id. at 116-17; 56 Cent. L.J. 303 (1903); 1 Wharton, Criminal Procedure 136 (10th ed. 1913).

104 In Carroll, this argument was suggested, but neither relied upon nor clearly grounded in the language of the amendment. 367 U.S. at 153. Accord, United States v. Di RE, 332 U.S. 581, 585 (1948).

105 This argument was made by Mr. Justice Frankfurter in his dissent to United States v. Rabinowitz, 339 U.S. 56,72 (1950), but was not related to the rule of reasonableness. In his dissent to Harris v. United States, 331 U.S. 145, 195 (1947), Mr. Justice Jackson suggested a rationale for the right to seize evidence of crime in a search incident to arrest: "Of course, a warrant to take a person into custody is authority for taking into custody all that is found upon his person or in his hands." Id. at 196. The warrant is for the arrest of a clothed person. 
clause at large. $106 \mathrm{~A}$ valid warrant was a sine qua non of the reasonableness of a search. Thus vehicle search and search incident to arrest were exceptions not only to the warrant requirement. They were exceptions to the amendment itself. 107 Until Rabinowitz, they were justified by reference to history alone.

The gradual expansion of the right of search incident to arrest during the first half of this century is too well known to require extended treatment.108 Four basic steps were involved: (1) In Weeks v. United States the Court first acknowledged, by dictum, "the right . . . always recognized under English and American law, to search the person of the accused when legally arrested to discover the fruits or evidences of crime."109 (2) In Carroll,110 again by way of dictum, the right was said to extend beyond the person of the arrestee to the area under his immediate control. (3) In Marron $v$. United States, 111 a broad extension occurred which arguably found no support in the underlying rationale. There, officers as incident to the arrest of a speakeasy operator during business hours searched the entire premises, seizing a ledger book found in a closet and various bills found in the room. A unanimous court stated that "the authority of officers to search and seize the things by which the nuisance was being maintained, extended to all parts of the premises used for the unlawful purpose."112 (4) In Harris v. United States, ${ }^{113}$ the broad right of search allowed in Marron was not limited to cases of arrest for criminal activities in progress. Rather, the Court upheld the validity of a painstaking search of arrestee's entire apartment which resulted in the seizure of contraband items totally unrelated to the offense for which the arrest had been made. 114

106 See Harris y. United States. 331 U.S. 145, 162 (1947) " 'Unreasonable' is not to be determined with reference to a particular search and seizure considered in isolation. The 'reason' by which search and seizure is to be tested is the 'reason' that was written out of historic experience into the Fourth Amendment" (Frankfurter, J., dissenting).

${ }^{107}$ See $i d$. at 168 . "The only exceptions to the safeguard of a warrant issued by a magistrate are those which the common law recognized as inherent limitations of the policy which found expression in the Fourth Amendment. ..." (Frankfurter, J., dissenting).

${ }^{103}$ See, e.g., Way, Increasing Scope of Search Incidental to Arrest, 1959 WASH. U.L.Q. 261; Fraenkel, Recent Developments in the Federal Law of Search and Seizure, 33 IowA L. REV. 472 (1948); Reynard, supra note 80, at 289-306. See United States v. Rabinowitz, 339 U.S. 56, 68 (1950) (Frankfurter, J., dissenting).

109232 U.S. 383, 392 (1914).

110267 U.S. at 158.

112 Id. at 199.

111275 U.S. 192 (1927).

113331 U.S. 145 (1947).

${ }_{114}$ A fifth step in the expansion of search incident to arrest may have occurred in $A b e l$, which arguably established that the fruits and instrumentalities of any crime are subjected to seizure if found in the course of a search, conducted in good faith, for objects related to the purpose for which the arrest was made. "When an article subject to lawful seizure properly comes into an officer's possession in the course of a lawful search it would be entirely without reason to say that he must return it because it was not one of the things it was his business to look for." 362 U.S. 217, 238 (1960). In citing this proposition to Harris, the Abel Court ignored the emphasis in Harris on the fact that the items there seized were contraband and property of the United States government. 331 U.S. at 154-55. See also Note, 107 U. PA. L. REv. 1192 (1959). 
Doctrinal developments do not reveal the full impact, however, which the growing right of search incident to arrest had on search and seizure law. For reasons already discussed, ${ }^{115}$ police resistance to full warrant requirements was strong. During the period of national prohibition it became stronger. Thus the full weight of law enforcement requirements came to bear upon the exception, and the exception grew to accommodate those needs. The end of Prohibition brought no substantial lessening of those needs, for federal responsibility in the enforcement of criminal statutes was rapidly expanding. 116 The exception-perhaps irrevocably —engulfed the rule, if patterns of police action 117 and frequency of cases are a proper indication. 118 Yet by eschewing a justification in the rule of reasonableness, the Court had forfeited the guidance which the amendment might supply.

Rabinowitz constituted a fundamental change in fourth amendment theory. First, the reasonableness clause became the dominant requirement of the amendment. For nearly a century, able commentators had understood warrants to be required for all searches, save for exceptions not grounded in the language of the Constitution. In addition, they read the amendment to require that warranted searches be conducted reasonably.119 After Rabinowitz, the issuance of search warrants would continue to be governed by the second clause, but it was the rule of reasonableness rather than a "rule of thumb" which determined when a warrant would be required.

Second, search incident to arrest, from its position as an historical exception, was brought squarely under the reasonableness clause of the amendment. 120 No immediate change in widely accepted search rights was involved, but the implications for fourth amendment theory were broad. If the rule of

115 See text accompanying notes 96-97 supra.

116 Cf. Hoover, Civil Liberties and Law Enforcement: The Role of the FBI, 37 IowA L. REv. 175 (1952).

117 From a 1952 sample of 770 arrests made in Philadelphia, only 24 , or $3 \%$, were authorized by warrants. Although searches of some kind were involved in most of the cases, "the use of search warrants in the cases examined was virtually non-existent." Note, Philadelphia Police Practice and the Law of Arrest, 100 U. PA. L. Rev. 1182 (1952); In Los Angeles County, only 17 search warrants were issued in 1954. See Barrett, Exclusion of Evidence Obtained by Illegal Searches-A Comment on People vs. Cahan, 43 CaLIF. L. REV. 565, 570 (1955) and authorities cited therein.

118 Out of approximately 30 search and seizure cases decided by the Supreme Court since the end of the Second World War, in only three does it appear that officers were acting even under color of the authority of a search warrant: Rea v. United States, 350 U.S. 214 (1956); Giordenello v. United States, 357 U.S. 480 (1958); Jones v. United States, 357 U.S. 493 (1958).

119 See Reynard, Freedom from Unreasonable Search and Seizure-A Second Class Constitutional Right? 25 IND. L.J. 259, 276 (1950) and authorities cited therein.

120 On occasion, however, the Court continues to speak of search incident to arrest as an exception to the basic search warrant requirement. See United States v. Jeffers, 342 U.S. 48, 51 (1951); Jones v. United States, 357 U.S. 493, 499 (1958); Rios v. United States, 364 U.S. 253, 261 (1960). See text accompanying notes 102-05 supra. 
reason could justify warrantless searches incident to arrest, other doctrines of warrantless, but reasonable, search were possible.121

Third, in making the reasonableness clause the dominant requirement of the amendment, Rabinowitz thrust to the center of fourth amendment litigation a test which had remained unused for more than a century and a half. The Court recognized that "What is a reasonable search is not to be determined by any fixed formula. The Constitution does not define what are 'unreasonable' searches and, regrettably, in our discipline we have no ready litmus-paper test. The recurring questions of the reasonableness of searches must find resolution in the facts and circumstances of each case."122

It was yet to be seen, however, whether the reasonableness clause was capable of sustaining a fundamental liberty. If there were no conclusive litmus-paper tests, were there any tests at all? Stare decisis would provide stability, but prior cases had been judged on different grounds. ${ }^{123}$ And what

121 One candidate for new treatment within this framework is the right to search moving vehicles, approved in Carroll v. United States, 267 U.S. 132 (1925). The argument from practical necessity there made, although not relied upon, foreshadowed a possible justification of the holding under the first clause of the amendment. Although Carroll was cited with approval in Brinegar v. United States, 338 U.S. 160 (1949), since Rabinowitz no occasion has arisen for the Court to reconsider the issue.

Apart from administrative searches, however, the Court had hesitated to acknowledge a doctrine of reasonable search not incident to arrest. In Chapman v. United States, 365 U.S. 610 (1961), officers searched petitioner's unoccupied house at the request of the landlord, and found an illegal distillery. The landlord's suspicions had been raised by a strong odor of whiskey mash coming from the house. Georgia law provided that the unlawful manufacture of distilled liquor on rented premises should work a forfeiture of the right of the tenant at the option of the landlord. Nevertheless the Court held the search violative of the fourth amendment on the grounds that (1) officers had time to secure a warrant; (2) a house could not be lawfully searched without a warrant, except as an incident to an arrest therein, notwithstanding facts unquestionably showing probable cause; and (3) until entry, the landlord did not know that the premises were being used for unlawful manufacture of liquor.

Although concurring in the result on the basis of his dissent in Rabinowitz, Mr. Justice Frankfurter chided the majority for refusing to uphold what he judged to be a reasonable, although warrantless, search under official Rabinowitz doctrine:

"The reasoning by which the Court reaches its result would be warranted were Trupiano ... still law.... Since the Rabinowitz case expresses the prevailing view, the decision in this case runs counter to it....

"Surely it is fair to say that the lower courts and prosecutors have a right to proceed on the assumption, on the basis of controlling decisions, that whether or not a search is 'unreasonable' turns on the circumstances presented by a particular situation, as a matter of substantive determination. On that test, I find it very difficult to conclude that a police officer may not deem adequate the authorization of a landlord to enter his house without a search warrant where he has solid ground for believing that his lessee is utilizing the house as an illegal distillery." Id. at 618-19.

122339 U.S. at 63.

123 Even the right of search incident to arrest, in whose name the reasonableness clause had been resurrected, was a stumbling block to logic. Mr. Justice Jackson had complained in Harris: "once the search is allowed to go beyond the person arrested and the objects upon him or in his immediate possession, I see no practical limit short of that set in the opinion of the Court-and that means to me no limit at all." 331 U.S. at 197 (dissenting opinion). 
of new circumstances where reason would be unaided by prior decisions? It is arguable that in $\mathrm{Abel}$, the reasonableness clause faced just such a test-and showed itself incapable of condemning what many thought to be a shocking invasion of constitutional liberties. 124

\section{The Reasonableness of Equivalent Protections}

In the previous section it was suggested that the fourth amendment's test of reasonableness was resurrected in Rabinowitz in order to accommodate the right of search incident to arrest. It was clear that that right could no longer be justified as a narrow but long-standing exception to warrant requirements. Without some formula or test to guide reason, however, the Rabinowitz Court may have set sail on a sea of doubt. It is now suggested that the required guidance might have been found in the warrant provisions of the amendment.

The principle upon which such an argument could be built may be found in an $\mathrm{Abel}$ dissent.125 In that case Mr. Justice Frankfurter had maintained that although the deportation arrest warrant did not have prior judicial approval, that fact should not impair the validity of the search. The situation was analogous, he argued, to search incident to a criminal arrest, which in Rabinowitz had been held valid without judicial approval.126 Mr. Justice Brennan, in dissent, strongly argued the dissimilarity of the two procedures. Although search incident to criminal arrest requires no prior judicial approval, the arrest which legitimizes such a search "may constitutionally be made only upon probable cause, the existence of which is subject to judicial examination ... and such an arrest demands the prompt bringing of the person arrested before a judicial officer, where the existence of probable cause is to be inquired into.... [T] here must be some inquiry into the over-all protection given the individual by the totality of the processes necessary to the arrest and the seizure."127

Mr. Justice Brennan sought to insure that the protections of search incident to administrative arrest would be equivalent to those of search incident to criminal arrest. From the standpoint of fourth amendment theory, a more

124 Curiously, a very different hypothesis may explain the vote of Mr. Justice Frankfurter. For him, "the Fourth Amendment incorporates a guiding history which gives meaning to the phrase 'unreasonable searches and seizures' contained within it far beyond the meaning of the phrase in isolation and taken from the context of that history and its gloss upon the Fourth Amendment." Chapman v. United States 365 U.S. 610, 619 (1961) (concurring opinion). Whether beyond, or simply differing from, ordinary usage, the meaning of the first clause of the amendment, for Mr. Justice Frankfurter, is contained in the rule of Trupiano. But when the first clause-and thus the second-are adjudged inapplicable to a case, as in $A b e l$, the amendment may be devoid of the further guidance which a more common reading of the language would provide.

125 Abel v. United States, 362 U.S. 217, 249-53 (1960) (Brennan, J., dissenting).

$126 \mathrm{Id}$. at $235-36$.

127 Id. at 249-51. 
useful rule would be one which demanded that the protections of search incident to any arrest be equivalent to the protections of warranted searches. Whatever else may have been the intent of the forefathers in drafting the first clause of the amendment, it would appear that searches conducted pursuant to the warrant provisions of the second clause fulfill the requirement of reasonableness. ${ }^{128}$ Therefore the warrant provisions may be employed as a touchstone to give some content to the reasonableness standard. Search procedures which give an "over-all protection" equal to that provided by full warrant procedures would, on this theory, be equally reasonable. ${ }^{129}$ But do searches incident to lawful arrest conform to this standard?

1. Basic to search warrant protections is the requirement of probable cause. Its function is to guarantee a substantial probability that the invasions involved in the search will be justified by discovery of offending items. Two conclusions necessary to the issuance of the warrant must be supported by substantial evidence: that the items sought are in fact seizable by virtue of being connected with criminal activity, and that the items will be found in the place to be searched. ${ }^{130}$ By comparison, the right of arrest arises only when a crime is committed or attempted in the presence of the arresting officer or when the officer has "reasonable grounds to believe"-sometimes stated "probable cause to believe"- that a felony has been committed by the person to be arrested.131 Although it would appear that the conclusions which justify either arrest or the issuance of a search warrant must be supported by evidence of the same degree of probity, 132 it is clear that the conclusions themselves are not identical.

In the case of arrest, the conclusion concerns the guilt of the arrestee, whereas in the case of search warrants, the conclusions go to the connection of the items sought with crime and to their present location. A general right of search, however, does not follow automatically from the fact of arrest. Rather, the Court has demanded that the search be reasonably and in good faith directed towards weapons by which an escape might be effected, or towards the fruits or instrumentalities of the crime for which the arrest was made.133

${ }^{128}$ But see text accompanying notes 79-87 supra; see Reynard, supra note 119, at 276, and authorities cited therein.

129 The seed of this theory may have been sown in a dissent to Trupiano: "To insist upon the use of a search warrant in situations where the issuance of such a warrant can contribute nothing to the preservation of the rights which the Fourth Amendment was intended to protect, serves only to open an avenue of escape for those guilty of crime and to menace the effective operation of government which is an essential precondition to the existence of all civil liberties." Trupiano v. United States, 334 U.S. 699, 714-15 (1948) (Vinson, C. J., dissenting).

130 See United States v. Old Dominion Warehouse, Inc., 10 F.2d 736, 738 (2d Cir. 1926). 131 See 18 U.S.C. $\S \S 3052-53$ (1950); Compare, e.g., 18 U.S.C. $\$ 3056$ (Supp. 1960).

${ }_{132}$ Cf. Draper v. United States, 358 U.S. 307, 310 n.3 (1959).

133 See Harris v. United States, 331 U.S. 145, 149-55 (1946). 
In the case of weapons, common knowledge of criminal behavior might argue that evidence sufficient to support a conclusion of guilt would also support the conclusion of possession. In the case of fruits and instrumentalities, the requirement of good faith may limit search rights to those cases in which the crime is of such a nature that evidence of commission indicates that certain fruits or instrumentalities were involved. 134

What remains to be supported by probable cause in the case of search incident to arrest is the conclusion that the fruits or instrumentalities sought will be found in the place of arrest. Here it must be admitted that however reliable may be the inference from the commission of a crime to the conclusion that certain types of fruits or instrumentalities were involved, the inference from the latter proposition to the conclusion that those items will be found at the place of arrest is far from compelling. Indeed, the probability that fruits or instrumentalities will be found at the place of arrest is only slightly greater than the probability that these items will be found in any place over which the arrestee has control.

Yet opposite conclusions may be drawn from this fact. It may be argued that since the probabilities of finding seizables is no greater in the place of arrest than in any other place controlled by the arrestee, as, for example, his car or garage, there are insufficient grounds to search any of these places. Alternatively, it may be argued with some plausibility that if fruits or instrumentalities were involved in the arrest crime, the probabilities that they are hidden in some place controlled by the arrestee is very high-sufficient, perhaps, to justify the issuance of warrants to search any of the places involved. 135 From this standpoint, the right of search incident to arrest is substantially narrower than a right which might be claimed by warrant, inasmuch as it permits the search of only the place of arrest.136

134 Cf. id. at $153-54$.

135 " $\Pi]$ can hardly be said that a reasonably cautious man would not be warranted in the belief that contraband diamonds or records pertaining to them would be found in the home, or any other place exclusively under the control, of the persons who were the alleged culprits." United States v. Klapholz, 17 F.R.D. 18, 24 (S.D.N.Y. 1955), aff'd, 230 F.2d 494 (2d Cir.), cert. denied, 351 U.S. 924 (1956). There, the affidavit upon which warrants were issued to search defendants' apartment and safe deposit box contained information showing only (1) that defendants were implicated in diamond smuggling, (2) their ownership of the places to be searched, and (3) the possibility that evidence of previous smuggling existed somewhere.

In Harris v. United States, 331 U.S. 145 (1946), federal agents obtained warrants to search both Harris' car and his private office. The affidavit upon which these warrants were secured alleged in addition to the information and belief upon which the arrest warrant had been issued only Harris' proprietary interest in the places to be searched. See Record, pp. 22-32.

${ }^{136} \mathrm{~A}$ certain randomness must be acknowledged in the selection of a particular place for arrest and search among several which defendant may happen to own or control. Mr. Justice Jackson suggested that officers would choose the place of arrest with a view to their desire to search. Harris v. United States, 331 U.S. 145, 197 (1946) (dissenting opin- 
2. A second protection which the fourth amendment provides in its requirements for search warrants is the particular description of items to be seized.137 If a general right of search followed from the fact of arrest, this protection would surely be lost.138 Insofar as the likelihood of uncovering specific categories of goods determines the scope of search incident to arrest, however, the two procedures would appear to be similar. What is avoided in either procedure is the "fishing expedition" in which entry is gained, ostensibly for the purposes of seeking one item, with the search becoming a general one for evidence of any offense. 139

It has been argued that in allowing the seizure of offending items unrelated to the arrest crime, the Court has recently abandoned this fourth amendment protection provided by warrant searches. ${ }^{140}$ In support of this contention, it must be acknowledged that under present rulings, items not particularly described in a warrant may not be seized. ${ }^{141}$ If the search which discovers unexpected items has been conducted in good faith, however, this rule cannot be justified by reference to additional invasions involved in seizing the items. That the seizure of items so discovered is not intrinsically violative of constitutional rights ${ }^{142}$ is demonstrated by the fact that no restriction is imposed

ion). Judge Learned Hand in an oft-quoted passage characterized this randomness somewhat differently: "True, by hypothesis the power would not exist, if the supposed offender were not found on the premises; but it is small consolation to know that one's papers are safe only so long as one is not at home." United States v. Kirschenblatt, 16 F.2d 202, 203 (2d Cir. 1926). It may be inaccurate to suppose, however, that one's papers are safe in a place for which the police could, at their option, obtain a search warrant. See note 135 supra. Moreover, it may be suggested that the requirement that a suspect witness warrantless searches of his property provides some modicum of additional protection.

137 U.S. Const. amend. IV; FED. R. CRIM. P. 41(c).

138 See Harris v. United States, 331 U.S. 145, 197 (1946) (Jackson, J., dissenting).

139 See id. at 149-50, 153-54; Abel v. United States, 362 U.S. 217, 225-30 (1956).

140 See generally Note, 34 N.Y.U.L. Rev. 159 (1959).

141 Long recognized has been the rule, however, that contraband, though not described in the search warrant, may be seized if found in the course of the search authorized thereby. Steele v. United States [No. 1], 267 U.S. 498 (1925) (by implication); United States v. Old Dominion Warehouse, Inc., 10 F.2d 736, 737 (2d Cir. 1926). Cf. Harris v. United States, 331 U.S. 145, 155 (1947): "If entry upon the premises be authorized and the search which follows be valid, there is nothing in the Fourth Amendment which inhibits the seizure by law-enforcement agents of government property, the possession of which is a crime, even though the officers are not aware that such property is on the premises when the search is initiated." But see Trupiano v. United States, 334 U.S. 699 (1948).

142 "The validity of a search and seizure as incident to a lawful arrest has been based upon a recognition by this Court that where law-enforcement agents have lawfully gained entrance into premises and have executed a valid arrest of the occupant, the vital rights of privacy protected by the Fourth Amendment are not denied by seizure of the contraband materials and instrumentalities of crime in open view or such as may be brought to light by a reasonable search." Trupiano v. United States, 334 U.S. 699, 714 (1947) (Vinson, C. J., dissenting). 
on officers securing additional warrants for this purpose. ${ }^{143}$ But it is urged that limitations on the fruits of search tend to limit the search itself to those bounds which good faith and prior authorization would allow.144 In this explanation lies the basic purpose of a rule limiting seizables to searchables. It would appear to be that of relieving the courts of the necessity of judging whether a search was in fact conducted reasonably and in good faith. Yet there is no indication that such a determination would tax the powers of the courts beyond those limits already required in the determination of a variety of fact issues. Indeed, it is precisely this sort of determination which a magistrate would be required to make were officers to seek a second warrant on the basis of information discovered in the course of a search made under a prior warrant. ${ }^{145}$ Assuming, then, that the determination of whether a search was conducted reasonably is not beyond the powers of the courts to make, the only protection lost by present rules on seizables is that provided by a second trip to a magistrate.

3. Of central importance to those who decry the growth of the right of search incident to arrest is the fact that such searches do not require the prior approval of a magistrate. Although probable cause alone justifies arrest and incidental search, it is the officer, rather than an independent magistrate, who makes the assessment of probabilities. It is to this point that Mr. Justice Jackson spoke in the passage already cited above: "The point of the Fourth Amendment ... is not that it denies law enforcement the support of usual inferences which reasonable men draw from evidence. Its protection consists in requiring that those inferences be drawn by a neutral and detached magistrate instead of being judged by the officer engaged in the often competitive enterprise of ferreting out crime."146

143 Should the first search be unlawful, officers cannot, of course, obtain a second warrant on the basis of information gained thereby, nor use the tainted information for any other purpose. See Silverthorne Lumber Co. v. United States, 251 U.S. 385 (1920). See also MAGUIRE, EVIDENCE OF GUILT 220-25 (1959), for a discussion of the general problem of attenuation.

144 See Note, 34 N.Y.U.L. Rev. 159 (1959).

145 Where a warrant for fruits or instrumentalities unrelated to the arrest crime was sought, the magistrate would be required to determine, in addition, the probable connection of the items sought with crime. Current restrictions on search incident to arrest may fall short of equivalent protections at this point. In the motion to suppress evidence of items unexpectedly found in the course of a search, inquiry should be made into (1) the legality of the arrest, (2) the good faith of the search for items related to the arrest crime, and (3) the reasons which officers had for believing that the items unexpectedly discovered were related to crime. In the case of contraband, the problem would not arise. See Harris v. United States, 331 U.S. 145 (1947). But in Abel, no inquiry was made into the officers' grounds for believing that the various paraphernalia seized were related to espionage.

The significance of this departure from equivalent protections should not be overemphasized, however. Since the discovery of unexpected items is, ex hypothesi, legal, the officer's oral testimony of what he saw would presumably be admissible into evidence, even if seizure were prohibited.

146 Johnson v. United States, 333 U.S. 10, 13-14 (1948). 
The right of search incident to arrest does not, of course, provide the protection of prior judicial approval. As Mr. Justice Brennan observed in his dissent to Abel, however, the arrest which legitimizes such a search carries with it the requirement that the arrestee be brought promptly before a judicial officer. ${ }^{147}$ There, or at a subsequent trial, the existence of probable cause is to be inquired into. 148 In assessing the validity of the arrest and search, the court may not consider information received by officers subsequent to the arrest or by means of the search. The inquiry on this issue presumably parallels that which would be undertaken by a magistrate before issuing a warrant. 149 Should insufficient cause for arrest be found, the coincident search will be invalid, and the evidence secured by the search suppressed, under the exclusionary rule. Where a search is subsequently found to be illegal, it is true that an absolute requirement of prior judicial approval would have prevented the invasion. Yet this protection would prevent only initial mistakes by inexperienced or confused officers. The theory behind the exclusionary rule as a sanction against illegal searches and seizures is that the officers, by being deprived of the "fruits" of illegal searches, will not continue to employ unlawful means of law enforcement; thus subsequent unjustified invasions will be prevented.150 Where the sanction of the exclusionary rule is ineffective to prevent illegal behavior by officers bent on harassment procedures, it is unlikely that an absolute warrant requirement would be more effective.

Had a doctrine of equivalent protections been accepted by the Court following Rabinowitz, there might have been no necessity to examine the basic objectives and interests at work in search and seizure law. No such doctrine has appeared, however. In this fact may lie the barest suggestion

147362 U.S. at 251-53.

${ }^{148}$ At the preliminary hearing, the Commissioner is to determine whether there is "probable cause to believe that an offense has been committed and that the defendant has committed it." FED. R. CRIM. P. 4(c). The admissibility of evidence is one for the trial court, however, and may not properly be decided by a commissioner at arraignment. Giordenello v. United States, 357 U.S. 480, 483-84 (1958). Thus where no search is made, or where the post-arrest investigation is unsuccessful, the Commissioner's determination would appear, on its face, to go to the issue of probable cause to arrest. But see generally Barrett, Personal Rights, Property Rights, and the Fourth Amendment, 1960 SuP. CT. REv. 46. Where evidence is secured by means of a post-arrest search, however, the issue of probable cause to arrest must await determination by the district court. See FED. R. CRIM. P. 41(e).

149 It is true that the movant in motions to suppress has the burden of proving the illegality of the search, whereas the government must bear the burden of proof when it seeks a ssearch warrant. See, e.g., Wilson v. United States, 218 F.2d 754 (10th Cir. 1955). But inasmuch as the "defendant" is never represented at the issuance of a warrant, his protections in the two proceedings may not be as disparate as it would appear.

150 "The rule is calculated to prevent, not to repair. Its purpose is to deter-to compel respect for the constitutional guaranty in the only effectively available way-by removing the incentive to disregard it." Elkins v. United States, 364 U.S. 206, 217 (1960). See, e.g., Brinegar v. United States, 338 U.S. 160, 181 (1949) (Jackson, J., dissenting). 
that the pressures which led to the demise of Trupiano demanded more than freedom from the mechanical burdens of obtaining a writ. Equivalent protections may be greater protections than should be granted for all searches and seizures.

\section{The Shadow of the Fifth Amendment}

In making the reasonableness clause the dominant requirement of the amendment, Rabinowitz affected a revolution in fourth amendment theory. The revolution was one of promise: all searches were to be brought within the scope of the amendment; variations in standards for criminal and administrative searches could be rationalized. But absent a doctrine of equivalent protections, the promise is contingent upon discovery of the objectives bearing upon reasonableness. The right of privacy and public law enforcement are the only desiderata which have been offered to guide judgment. Frank taught that they were incapable of justifying even existing standards on search and seizure; much less can this two-value analysis guide the subtle re-fashioning of standards which continual conflicts demand.

A quest for the additional objectives which may influence the Court is required. A return to Frank v. Maryland provides the proper starting place.

There, it was seen, Mr. Justice Frankfurter distinguished between two protections which emerged from the amendment. The second of these was "self-protection: the right to resist unauthorized entry which has as its design the securing of information to fortify the coercive power of the state against the individual, information which may be used to effect a further deprivation of life or liberty or property.... It is this aspect of the constitutional protection to which the quoted passages from Entick v. Carrington and Boyd v. United States refer."151

The passages quoted from Entick and Boyd, and the broader decisions from which they were drawn, must be examined with care, for out of these cases came "the mystic union" of the fourth and fifth amendments152 which has had interesting effects on search and seizure law. Entick v. Carrington153 involved an action in trespass against officers of the Crown, arising from a search of plaintiff's home and the seizure of his private papers. The search was made pursuant to a general executive warrant, charging plaintiff with seditious libel. The great question before Lord Camden was whether a warrant to search for and seize a citizen's private papers could ever be lawful. He argued that:

[T]he great end, for which men entered into society, was to secure their property. That right is preserved sacred and incommunicable in all instances, where it has

151359 U.S. at 365.

${ }^{152}$ Cf. Allen, The Wolf Case: Search and Seizure, Federalism, and the Civil Liberties, 45 ILL. L. REv. 1, 22 (1950).

15319 How. St. Tr. 1029 (1765). 
not been taken away or abridged by some public law for the good of the whole.... By the laws of England, every invasion of private property, be it ever so minute, is a trespass. No man can set his foot upon my ground without my license, but he is liable to an action.... If he admits the fact, he is bound to show by way of justification, that some positive law has empowered or excused him.... If no such excuse can be found or produced, the silence of the books is an authority against the defendant, and the plaintiff must have judgment. ${ }^{154}$

By this test Lord Camden examined all suggested justifications for the trespass and found them inapplicable. The last which he considered was, "an argument of utility, that such a search is a means of detecting offenders by discovering evidence. I wish some cases had been shown, where the law forceth evidence out of the owner's custody by process.... In the criminal law such a proceeding was never heard of.... [O]ur law has provided no paper-search in these cases to help forward the prosecution."155

Having found no prior authority for the trespass, Lord Camden turned to the positive arguments for the denial of the right claimed: "Whether this proceedeth from the gentleness of the law toward criminals, or from a consideration that such a power would be more pernicious to the innocent than useful to the public, I will not say."156 The paragraph quoted by Mr. Justice Frankfurter followed immediately:

It is very certain, that the law obligeth no man to accuse himself; because the necessary means of compelling self-accusation, falling upon the innocent as well as the guilty, would be both cruel and unjust; and it should seem, that search for evidence is disallowed upon the same principle. There too the innocent would be confounded with the guilty.

Observe the wisdom as well as mercy of the law. The strongest evidence before a trial, being only ex parte, is but suspicion; it is not proof. Weak evidence is a ground of suspicion, though in a lower degree; and if suspicion at large should be a ground of search, especially in the case of libels, whose house would be safe?157

It is clear that Entick provides no basis for a doctrine of interrelation between the fourth amendment and the self-incrimination clause of the fifth. The warrant in Entick fails for lack of an authoritative justification which will overcome the prima facie case of trespass. That the need to discover evidence of crime provides no such justification is positively supported on alternative theories of "the gentleness of the law toward criminals" and of the inherent difficulty in selecting the proper persons to subject to the invasions involved. The second theory turns, in effect, upon a question of probable cause. For Lord Camden, the serious invasion involved in the seizure of a citizen's private papers could, at best, find its justification only in the guilt of the individual. But to justify such an invasion solely by the
154 Id. at 1066.
155 Id. at 1073.
156 Ibid.

157 Id. at 1073-74. The second paragraph was not quoted in Frank. 
evidence of crime which it might uncover was to admit that the individual was merely a suspect, not a proven criminal.

Compulsory self-accusation was disallowed on the same theory. In both cases, invasions of civil liberties, justifiable only by proven guilt, were themselves used to secure proof of guilt. The danger common to both procedures was that the innocent would be confounded with the guilty.

The first ground on which Lord Camden had dismissed the claim that general warrants were justified by the need to discover evidence of crime was "the gentleness of the law toward criminals." He did not expand on the notion. What may have been intended was the view that certain techniques of law enforcement are so violative of civil liberties as to be repugnant to the conscience of the community. An analogy to the fifth amendment could again be drawn, for one of the justifications for its protections has been the moral judgment that compelling self-accusation would be an unconscionable exercise of state power.158

In Boyd v. United States 159 the union of the fourth and fifth amendments was made, based, it would appear, on a misreading of Lord Camden's analogies. The case involved a challenge to the constitutionality of a statutory provision of the federal revenue laws. The statute provided that in forfeiture proceedings instituted for the alleged non-payment of import duties, the court might issue a notice to defendants requiring the production in court of relevant books and records. Upon failure of the defendant to comply with the orderwhich was, in form, like a subpoena duces tecum-the allegations of the government as to the contents of the papers were to be taken as confessed by the defendant.

A minority of the Court thought the statute unconstitutional under the self-incrimination clause of the fifth amendment. However, Mr. Justice Bradley, speaking for the majority, concluded that the validity of the statute was to be judged primarily under the fourth. He argued: "It is true that certain aggravating incidents of actual search and seizure, such as forcible entry into a man's house and searching amongst his papers, are wanting... but it accomplishes the substantial object of . . . forcing from a party evidence against himself."160 That the "search and seizure" permitted by the statute was unreasonable under the fourth amendment was argued on much the same pattern as in Entick. The violations of an individual's security could only be justified by an independent proprietary-like interest which the state had in the objects to be seized. No such interest existed in the case of personal papers which normally had, for the state, only evidentiary value. In support of this contention, the Court quoted at length from Entick v. Carrington,

158 See, e.g., Griswold, The Fifth Amendment Today 7-8 (1955); Maguire, op. cit. supra note 143 , at 14 .

159116 U.S. 616 (1886).

$160 I d$. at 622. 
ending with the analogy to self-incrimination there drawn. Mr. Justice Bradley summarized:

It is not the breaking of his doors ... that constitutes the essence of the offence; but it is the invasion of his indefeasible right of personal security, personal liberty and private property ... which underlies and constitutes the essence of Lord Camden's judgment.... Any forcible and compulsory extortion of a man's own testimony or of his private papers to be used as evidence to convict him of crime or to forfeit his goods, is within the condemnation of that judgment. In this regard the Fourth and Fifth Amendments run almost into each other.161

The basis for the relationship between the two amendments was stated in the following passage, later quoted in Frank:

We have already noticed the intimate relation between the two amendments. They throw great light on each other. For the "unreasonable searches and seizures" condemned in the Fourth Amendment are almost always made for the purpose of compelling a man to give evidence against himself, which in criminal cases is condemned in the Fifth Amendment; and compelling a man "in a criminal case to be a witness against himself," which is condemned in the Fifth Amendment throws light on the question as to what is an "unreasonable search and seizure" within the meaning of the Fourth Amendment. And we have been unable to perceive that the seizure of a man's private books and papers to be used in evidence against him is substantially different from compelling him to be a witness against himself.162

It may be fair to say that for the past half-century, scholars have been unable to perceive the "intimate relation" which Mr. Justice Bradley detected between the two amendments. ${ }^{163}$ Part of the problem may lie in the knowledge of subsequent cases which modern commentators bring to their interpretation of Boyd. Boyd was the first fourth amendment case of any importance to reach the Supreme Court.164 The warrant clause of the amendment was applicable to all searches, with narrow exceptions, but no gloss had been placed on the requirement of reasonableness. The only guidelines available were English decisions from the time of Entick.165 Under these circumstances, the Court apparently concluded that the function of the reasonableness

$161 \mathrm{Yd}$. at 630.

$162 \mathrm{Id}$. at 633.

163 See, e.g., Wigmore, EVIDENCE $\$ 2264$ (3d ed. 1940); MAGUIRE, op. cit. supra note 143 , at $\$ 2.04$; Corwin, The Supreme Court's Construction of the Self-Incrimination Clause, 29 Mrch. L. Rev. 1, 16 (1930); Meltzer, Required Records, The McCarran Act, and the Privilege against Self-Incrimination, 18 U. CHI. L. Rev. 687, 699-701 (1951). The Boyd position was anticipated, however, in Cooley, Constrtutional Limitations 305-07 (1868).

${ }^{164}$ The dearth of cases reaching the Court during the first century of the amendment's operation may be explained, in part, by the fact that no right of appeal to the Supreme Court in criminal cases was granted until 1891. 26 Stat. 827 (1891), 28 U.S.C. $\$ 346$ (1926).

${ }^{165}$ In addition to Entick, see, e.g., Wilkes' Case, 19 How. St. Tr. 981 (1763); Leach v. Money, 19 How. St. Tr. 1001 (1765). 
clause was to prohibit warranted searches for merely evidentiary objects. 166

In Entick the prohibition had been based, essentially, on a theory of probable cause. In Lord Camden's view, to search for merely evidentiary materials was to concede that the Crown possessed insufficient evidence to justify the search. By misreading the Entick analogy, however, Mr. Justice Bradley understood the decision to be based on a rule of evidence. That rule, which antedated Entick ${ }^{167}$ and is incorporated into the fifth amendment, ${ }^{168}$ protects a witness against the compulsory production of documents or chattels for use in evidence in a criminal trial. Although sometimes criticized, ${ }^{169}$ the rule was properly applied in Boyd where the admissibility of a document produced under compulsion of law was in issue. Entick, however, involved an action for damages in trespass. The use to which the seized articles would be put was not at issue. 170 The privilege against self-incrimination, thus, was no more relevant there than it would be in an action against a police officer for assault in obtaining a confession.

For several years following Boyd the Court appeared unwilling to follow the suggested theory of fourth and fifth amendment interrelation. ${ }^{171}$ The shadow of the fifth had been cast on search and seizure law, however, and would not easily be dispelled. As befits the shifting outlines of a shadow,

166 This position was subsequently supported by several commentators. See, e.g., Reynard, Freedom from Unreasonable Search and Seizure-A Second Class Constitutional Right 725 IND. L.J. 259, 276 (1950); Corwin, supra note 163, at 15-27.

167 See, e.g., Rex v. Purnell, 1 W. Bl. 37, 45 (1749). See also Roe v. Harvey, 4 Burr. 2484, 2489 (1769).

168 See generally Morgan, The Privilege against Self-Incrimination, 34 MINN. L. REv. 1, 34-38 (1949) and cases cited therein.

169 See, e.g., Meltzer, supra note 163, at 699-701.

170 Wigmore argued that before Boyd, the rule applied only to "the production of documents or chattels by a person (whether ordinary witness or party-witness) in response to a subpoena, or to a motion to order production, or to other form of process treating him as a witness (i.e. as a person appearing before the tribunal to furnish testimony on his moral responsibility for truth-telling)...." The privilege against self incriminationalthough directed primarily at oral admissions-must include documents produced under these circumstances, he reasoned, because the witness "would be at any time liable to make oath to the identity or authenticity or origin of the articles produced." 8 WIGMoRE, op. cit. supra note 163 , at $\S 2264$. This rationale is criticized in Meltzer, supra note 163 , at 700. For a reformulation of the Wigmore rationale which may avoid the criticism, see MAGUIRE, op. cit. supra note 143, at 23.

Where, as in Entick, documents or chattels are seized under circumstances in which the owner is not "treated as a witness"-or, in Maguire's terms, is not required to participate in the incriminatory process by responding to a descriptive demand-Wigmore argues that the materials may be used evidentially. 8 WIGMORE, op. cit. supra note 163 , at $\$ 2264$ and cases cited therein. This is a part, of course, of Wigmore's broader criticism of the exclusionary rule of evidence. Insofar as the claim accurately states the rule at the time of Entick, however, it lends support to the suggested reading of that case. See Francia's Trial, 15 How. St. Tr. 897, 966 (1717).

171 See, e.g., Hale v. Henkel, 201 U.S. 43 (1906); ICC v. Baird, 194 U.S. 25 (1940); Adams v. New York, 192 U.S. 585 (1904). 
the fifth amendment was subsequently cited in support of a variety of propositions in search and seizure cases. The rule prohibiting the search for, or seizure of, "merely evidential materials," was cited to Boyd and justified by general reference to the fifth amendment.172 Occasionally, it was suggested that searches not involving private papers were illegal under both the fourth and the fifth amendments, recalling the widespread interaction which Mr. Justice Bradley saw at work. 173 In the early cases following Weeks, and more recently in Mapp v. Ohio, the federal exclusionary rule was justified by reference to the fifth. ${ }^{174} \mathrm{Mr}$. Justice Frankfurter disclaimed any particular theory concerning the interrelation of the amendments in Frank, but the distinction there drawn between searches for evidence of crime, and searches for rats or rubbish, was supported by reference to Entick and Boyd.175

To inveigh against the Boyd theory of the intimate relation between the amendments should not lead to a disregard of the beneficial influence which fifth amendment analogies have had on search and seizure law. Yet the lessons to be learned from the analogies may never have been better drawn than in Entick.

The first is this. One of the dangers to be avoided by the privilege against self-incrimination is said to be that posed by the "lazy prosecutor" who, absent the protection, would rely on compulsory self-incrimination rather than less invasive procedures to develop his cases. 176 Lord Camden suggested that search and seizure were subject to the same danger. To invade precious civil liberties by either technique for the purpose of securing evidence, is inevitably to subject innocent persons to some phase of the criminal process.

The first counsel of fifth amendment analogies, then, is directed against the use of search and seizure as an investigative technique. The fourth amendment requirement of probable cause for the issuance of warrants reflects the same concern, as does the demand that non-warrant searches normally be conducted co-incident with arrest. 177 Yet the analogy is not taken as a

172 See Gouled v. United States, 255 U.S. 298 (1921); Weeks v. United States, 232 U.S. 383 (1914).

173 McGuire v. United States, 273 U.S. 95 (1927); Gambino v. United States, 273 U.S. 310 (1927).

174 See, e.g., Agnello v. United States, 269 U.S. 20 (1925); Marron v. United States, 275 U.S. 192 (1927); Mapp v, Ohio, 367 U.S. 643 (1961).

175 Frank v. Maryland, 359 U.S. 360, 365 (1959).

176 See 8 Wigmore, op. cit. supra note 163, at $§ 2251$. But see Meltzer, supra note 163, at 690 .

177 The federal requirement that an arrestee be brought before a committing magistrate without unreasonable delay (see FED. R. CRIM. P. 5; Mallory v. United States, 354 U.S. 449 (1957)) entails the notion that probable cause to arrest will be sufficient grounds for arraignment. ("Arraignment" is used here as a shorthand term. See MAGurRe, op. cit. supra note 143, at 161-62.) Were such a standard to be imposed rigorously, search incident to arrest would seldom be necessary or useful as an investigative technique. See generally Barrett, supra note 148. 
counsel of perfection, however absolute may be the prohibition against compulsory self-incrimination. To construct a similarly absolute rule against the seizure of merely evidentiary objects is to ignore the fact that an alleged proprietary interest of the state in the objects of seizure is no guarantee against harassment of the innocent. And to demand conclusive proof of guilt before countenancing the invasions involved in search is to ignore the gravity of competing interests in law enforcement and other community needs.

A calculus of reason is evidently required. But in the computation it cannot be forgotten that search and seizure, particularly in the absence of a warrant, come at an early stage in the law enforcement process. The danger of confounding the innocent with the guilty is greater here than in subsequent stages, which may be reached only after a variety of judicially-controlled checks.

The second analogy supported by Entick casts a shadow of indeterminate length on search and seizure law. It turns on the notion of enforcement techniques so violative of human dignity as to be repugnant to the conscience of the community. The concept eludes justificatory analysis because of its proximity to the core of the society's value system. The state may imprison a man, but it may not flog him. It may execute him, but it may not torture him. It may compel him to testify against his father, but it may not demand that he incriminate himself. Judgments of this character might well be unaffected by the certain assurance that the techniques would only be directed against the guilty. Such notions may well lurk at the periphery of the fourth amendment. The Court has reflected them in its summary disposition of several search and seizure cases involving extreme violations of individual rights. ${ }^{178}$ But other cases, very nearly as shocking, have evoked no such reaction. 179 Something approaching a fundamental moral judgment may have led to the absolute rule against seizing private books and papers. If so, the judgment was short-lived, for the rule was sapped of its vitality by subsequent cases. 180

The future influence of basic ethical notions on search and seizure law is difficult to predict. The greatest deterrant of their growth is the fact of established practices and the pressure of collective needs for effective law enforcement. For this reason, their influence may be a conservative one-that of resisting any relaxation of current safeguards on rights of search.

178 See, e.g., Rochin v. California, 342 U.S. 165 (1952) (emetic used to recover capsules of morphine which defendant had swallowed when officers forced their way into his bedroom).

179 See, e.g., Breithaupt v. Abram, 352 U.S. 432 (1957) (blood sample taken to determine intoxication while petitioner was unconscious following automobile accident in which he was involved). See also Irvine v. California, 347 U.S. 128 (1954).

180 See, e.g., Marron v. United States, 275 U.S. 192 (1927). 


\section{The Hedge against Bad LAw}

The fourth amendment was drafted during a period when the law was in disrepute.181 The major growth of search and seizure law came in cases arising under the National Prohibition Act.182 Out of those cases, the rulings most restrictive on search and seizure practices appeared in the early 1930's after Prohibition had lost much of its popular support.183 A high water mark in safeguards on search and seizure was reached shortly following the Second World War, when the memory of European experience with totalitarian rule was still clear in the mind of the Court. ${ }^{184}$ Correlations of this kind have led to suggestions that judicial distrust or disapproval of the law itself has occasionally had an influence on both search and seizure standards and on the exclusionary rule of evidence.185

For any calculus of reasonableness to operate, some assessment must be made of the gravity of the law enforcement interests which is sought to justify particular invasions of civil liberties. ${ }^{186}$ But to suggest that some restrictions on search and seizure practice have as their sole purpose making more arduous the conviction and punishment of the guilty is quite a different matter. The charge would, at worst, be that of judicial nullification; at best, that of using Bentham's "fox hunter's reason," or of undue "sentimentality" towards offenders. ${ }^{187}$

No such charge is here made. What is suggested is that the cases reveal hints of the theory that the substance of the law itself may be influenced by the enforcement techniques available to it. Dissenting in Harris v. United States, Mr. Justice Murphy argued:

The principle established by the Court today can be used as easily by some future government determined to suppress political opposition under the guise of sedition as it can be used by a government determined to undo forgers and defrauders.... History is not without examples of the outlawry of certain political, religious and economic beliefs and the relentless prosecution of those who dare to

181 See Lasson, The Hustory and Development of the Fourth Amendment to the UNITED States Constirution 52, 67-69 (1937); Reynard, The Right of Privacy, in Fundamental Law in Criminal Prosecutions 85, 88 (Harding ed. 1959).

182 See, e.g., Carroll v. United States, 267 U.S. 132 (1925); Byars v. United States, 273 U.S. 28 (1927); Marron v. United States, 275 U.S. 192 (1927).

183 See Go-Bart Importing Co. v. United States, 282 U.S. 344 (1931); United States v. Lefkowitz, 285 U.S. 452 (1932).

184 See Johnson v. United States, 333 U.S. 10 (1948); Trupiano v. United States, 334 U.S. 699 (1948).

185 See, e.g., PuttKammer, Administration of Criminal Law 80-81 (1953); Waite, Reasonable Search and Research, 86 U. PA. L. REv. 623 (1938); WIGMORE, op. cit. supra note 163 , at $\$ 2184$.

186 Cf. Brinegar v. United States, 338 U.S. 160, 183 (1949) (Jackson, J., dissenting).

187 See WIGMORE, op. cit. supra note 163 , at $\$ 2184$; $c$. MAGUIRE, EVIDENCE OF GuILT 12 (1959). 
entertain such beliefs. And history has a way of repeating itself. It therefore takes no stretch of the imagination to picture law enforcement officers arresting those accused of believing, writing or speaking that which is proscribed, accompanied by a thorough ransacking of their homes as an "incident" to an arrest in an effort to uncover "anything" of a seditious nature. Under the Court's decision, the Fourth Amendment no longer stands as a bar to such tyranny and oppression. ${ }^{188}$

It is clear that the danger to which Mr. Justice Murphy referred is not simply that of over-bearing police in an otherwise democratic society. Rather, he warns that the availability of broad police powers will encourage, or at least provide no hedge against, the deterioration of the political order itself. $\mathrm{Mr}$. Justice Frankfurter spoke in much the same vein in his dissent in Harris: "How can there be freedom of thought or freedom of speech or freedom of religion, if the police can, without warrant, search your house and mine from garret to cellar merely because they are executing a warrant? . . . Yesterday the justifying document was an illicit ration book, tomorrow it may be some suspect piece of literature."189 Davis v. United States evoked similar warnings: "It is not only under Nazi rule that police excesses are inimical to freedom. . . . History bears testimony that by such disregard are the rights of liberty extinguished, heedlessly at first, then stealthily, and brazenly in the end."190 The latter passage might seem to suggest that the danger to be avoided is the slow erosion of all traditional liberties. If this were the crux of the problem the fourth amendment would not be properly viewed as a special "bar to such tyranny and oppression." A careful reading of the passages indicates, however, a theory of unique relation between broad powers of search and seizure and the rise of a totalitarian state. Totalitarian regimes may be characterized, in part, by the types of offenses with which they are most concerned: sedition, heresy, unpopular thought, disapproved literature. These are all "victimless crimes," or at least crimes of which the government is the only victim. Search and seizure procedures are uniquely suited-perhaps indispensible - to the detection of just such crimes. It is reasonable to suppose, therefore, that strict controls on the right of search and seizure would provide one hedge against the kind of oppressive law which only such procedures could make enforceable.

It is arguable that broad powers of administrative search would provide as useful a vehicle for oppression as would similar powers to search for evidence of crime. That position was urged by Mr. Justice Douglas in his dissent in Frank,191 and may have been demonstrated in Abel. Nevertheless, the principle may support some distinction between searches for evidence of crime and searches for rats and rubbish. That the distinction should turn

188331 U.S. 145, 194 (1947).

189 Id. at 163.

190328 U.S. 582, 597 (1946) (Frankfurter, J., dissenting).

191359 U.S. at 375. 
on the broad concept of "administrative processes," however, may be open to doubt.

\section{INJURY to REPUTATION}

From the shadow of the fifth amendment was drawn the warning that searches for evidence of crime will inevitably violate the civil liberties of the innocent as well as the guilty. The proportion of innocent who suffer, to guilty whose crimes are detected, will be a function of the quality of pre-search information required. In setting the standards of probable cause, an assessment must be made of the degree to which innocent men will suffer from mistaken searches.

Whether the search be for rubbish or narcotics, both innocent and guilty will suffer the loss of the proprietary right of privacy. 192 The search for evidence of crime, however, threatens the innocent with an injury not recognized in the cases. That is the damage to reputation resulting from an overt manifestation of official suspicion of crime. Connected with loss of reputation, standing, or credit may be humiliation and other mental suffering. The interests here at stake are the same which are recognized in the common law actions for defamation and malicious prosecution. 193 Indeed, the loss of reputation and the humiliation resulting from the search of one's home for evidence of a heinous crime may greatly exceed the injury caused by an illgrounded prosecution for a minor offense.

Curiously, the risk of injury to reputation may vary directly with the quantum of pre-search information required. A road block and search of all passing cars for fleeing robbers implies only limited suspicion of any given driver; a house-to-house search for a notorious criminal thought to be in the neighborhood may be equally innocuous from this standpoint. What the innocent citizen has most reason to fear is being singled out as the object of official suspicion. Although illegal search and seizure does not give rise to an action for malicious prosecution or defamation, the interests protected by those actions might properly influence the courts in determining requirements for search and seizure.

\section{CONCLUSION}

The fourth amendment, like the due process clause of the fourteenth, has been heavily overworked in the absence of specific legislation implementing its general directives. As with all constitutional provisions, the fourth must ultimately derive its content from the sensibilities of a democratic society. Yet the determinants at work in this area of the law have often been obscureeven, one feels, to the Court itself.

Trupiano and Rabinowitz constituted a theoretical watershed in fourth amendment litigation. A half-century of prior cases had been peculiarly

192 See id. at 382.

193 See generally Prosser, ToRTs 572-84, 645-62 (2d ed. 1955). 
devoid of analytical content. The constitutional provision which the Court was expounding in search and seizure cases was the warrant clause of the fourth amendment. That clause, more legislative than constitutional in flavor, veiled by its very specificity the formlessness of the fundamental liberty it protected. By the time that Trupiano articulately stated the rule which the Court was enforcing, the rule had already been drained of vitality by exceptions, and had been made obsolete by accepted law enforcement practices.

Rabinowitz was a child of promise. Like Trupiano it sought to bring all searches within the structure of the amendment. Unlike Trupiano, perhaps, it sought an accommodation with law enforcement concerns, the frustration of which threatens all liberties. The basis of that accommodation was found, if not in the minds of the forefathers, at least in the language of the Constitution. The warrant clause would continue to guard against general writs; indeed, reason might require that warrants be secured for many searches. But only the reasonableness clause could sustain exceptions which had engulfed old rules. To its protection was committed the fundamental liberty which the amendment established.

But the promise of Rabinowitz was not fulfilled. Reasonableness demands reasons. Only the proprietary right of privacy and the need for law enforcement were offered. The parthenogenetic progeny, first of one, then of the other of these objectives were Abel,194 Silverman, ${ }^{195}$ and Chapman.196

The application of the rule of reasonableness was not the only problem. In other cases, the rule itself was placed in doubt. Less than two years after Rabinowitz, a new majority stated that "over and again this Court has emphasized that the mandate of the Amendment requires adherence to judicial processes. . . . Only where incident to a valid arrest ... or in 'exceptional circumstances,' may an exemption lie, and then the burden is on those seeking the exemption to show the need for it...."197 Johnson v. United States ${ }^{198}$ and McDonald $v$. United States, 199 both from the Trupiano period, were cited as authority. Similar language is found more recently in Jones v. United States: "The exceptions to the rule that a search must rest upon a search warrant have been jealously and carefully drawn, and search incident to valid arrest is among them."200 In Chapman v. United States, Johnson is again relied upon: "No reason is offered for not obtaining a search warrant except for the inconvenience to the officers.... These are never very convincing reasons and, in these circumstances, certainly are not enough to bypass the constitutional requirement." "201 The disturbing factor in these

194 See text accompanying notes 34-41 supra.

195 Silverman v. United States, 365 U.S. 505 (1961). See text accompanying notes 62-64 supra.

196 Chapman v. United States, 365 U.S. 610 (1961); see note 121 supra.

197 Jeffers v. United States, 342 U.S. 48, 51 (1951).

198333 U.S. 10 (1948).

200357 U.S. 493, 499 (1958).

199335 U.S. 451 (1948).

201365 U.S. at 615. 
cases is the theoretical indecision which their language reveals. The exclusionary rule, like all deterrent systems, is genuinely effective against only those offenses involving an element of scienter. But repeatedly, members of the Court have protested against the confusing pattern which the cases present to law enforcement officers.

An alternative explanation may be given to the obiter dicta in Jeffers, 202 Jones and Chapman. They may foreshadow an eventual return of the Court to the rule of Trupiano. Interestingly, a five man "minority" of the present Court, not recently coalesced, profess continued sympathy with that position. ${ }^{203}$ Yet the probability that Rabinowitz will be overruled would appear to be small. Trupiano, Johnson, and McDonald offer a convenient arsenal of weapons against disapproved searches. The common bond among the minority of five, however, is not strong. Mr. Justice Frankfurter bows to Trupiano as a mandate of history; were "reasonableness" to him not a word of art, his votes in Abel and Chapman might well have been reversed.204 For the Chief Justice, and Justices Douglas and Brennan, it is a non-technical interpretation of "reasonableness" which demands a return to Trupiano. 205 The framework they seek is not that of the early commentators; but even when read conventionally, "reasonableness," for them, requires that warrants be employed whenever practicable. Mr. Justice Black originally opposed the rule of Trupiano.206 In Rabinowitz, however, he dissented, arguing that the orderly administration of justice required that Trupiano, once established, be accorded a fair test of time.207 The theory which supports his continued sympathy for the rule is not clear.

Additional considerations argue against a return to Trupiano. The administrative search cases present a complex obstacle. Four members of the "minority"208 are unwilling to accept the distinction between criminal and administrative searches. Yet it would seem unlikely that searches for rats and rubbish could long be subjected to the stringency of the former rule.209

Even more difficult would be the problem of accommodation with law enforcement concerns. Since Wolf $v$. Colorado 210 there has been a movement toward imposing increasingly strict standards upon searches by state of-

202 Jeffers v. United States, 342 U.S. 48 (1951).

${ }_{203}$ Mr. Justice Frankfurter (Chapman v. United States, 365 U.S. 610, 618 (1961) (concurring)); Justices Douglas, Black, Brennan, and the Chief Justice (Frank v. Maryland, 359 U.S. 360,380 (1959) (Douglas, J., dissenting)).

204 Cf., e.g., Chapman v. United States 365 U.S. 610, 618 (1961) (concurring opinion).

${ }^{205}$ Cf., e.g., Abel v. United States, 362 U.S. 217, 248 (1960) (dissenting opinion).

206334 U.S. at 710.

207339 U.S. at 66.

208 Justices Douglas, Black, Brennan, and the Chief Justice. See Frank v. Maryland, 359 U.S. 360, 374 (1959) (dissenting opinion).

${ }^{209}$ Even the dissenters in Frank recognized that more liberal warrant requirements might be necessary in health inspection cases. 359 U.S. at 383.

210338 U.S. 25 (1959). 
ficers. 211 Four of the five justices who favor Trupiano appear to maintain that all fourth amendment standards are made applicable to the states through the due process clause of the fourteenth.212 Were this doctrine of Elkins $v$. United States 213 to be combined with a return to Trupiano standards, the Court might be subject to extreme pressures from state law enforcement agencies.

If a return to Trupiano is impracticable, what alternative is available to the Court? A half-century of conflicts frames the scope of the problem: prevailing search practices must be brought within the outlines of the amendment. Warrants must find a clear rationale. Searches for rats and rubbish must be distinguished from searches for evidence of crime on grounds and by concepts reflecting the objectives of the law. Electronic surveillance must respect the liberty of the amendment, rather than the perimeters of the close. Finally, the full objectives of search and seizure law must be articulated and applied to ever-changing patterns of crime and investigation.

If the promise of Rabinowitz pales before the complexities of the problems, it may nevertheless suggest initial steps toward their resolution. Some of the reasons demanded by the rule of Rabinowitz may be found in Frank. Their use suggests a calculus by which reasonableness may be determined. In Frank, three considerations bore on the Court's evaluation of the search: the community need which prompted the search, the seriousness of the invasions on privacy involved, and the probabilities of success in discovering offending conditions. To be sure, the right to search for evidence of crime must be surrounded with safeguards substantially greater than those controlling inspectors of rats and rubbish. Rather than making a calculus of reason inapplicable, however, this fact simply demands that all relevant considerations be brought to bear on the calculus. Criminal searches often involve, in addition to invasions of privacy, substantial damage to reputation. This fact, coupled with the lesson from Entick that some searches for evidence of crime inevitably will be directed at innocent persons, provide a calculus factor capable of demanding higher standards of criminal searches.

Yet even this expanded calculus might not put all proper fears to rest. Such a calculus might permit shocking invasions where the community need was great and the probabilities of guilt high. However useful the calculus in evaluating common searches, some outer limits must be set on its operation.

211 See Rochin v. California, 342 U.S. 165 (1952); Elkins v. United States, 364 U.S. 206 (1960); Mapp v. Ohio, 365 U.S. 643 (1961).

212 See e.g., Frank v. Maryland, 359 U.S. 360, 374 (1959) (dissenting opinion); Elkins v. United States, 364 U.S. 206 (1960). The fifth, Mr. Justices Frankfurter, adamantly opposes the view. See Elkins v. United States, 364 U.S. 206, 233 (1960) (dissenting opinion).

213364 U.S. 206 (1960). In Elkins, the Court held that "evidence obtained by state officers during a search which, if conducted by federal officers, would have violated the defendant's immunity from unreasonable searches and seizures under the Fourth Amendment is inadmissible ... in a federal criminal trial." 364 U.S. at 223. 
Those limits, it is suggested, can be found in the basic notions-encountered above as shadows on the amendment-of civilized standards of law enforcement and hedges against bad law. Any search and seizure would have to fall inside these outer limits before it could be tested by the calculus of reason.

The operation of such a pattern would not be very different from the way in which the Court has decided a number of recent cases. In Rochin v. California ${ }^{214}$ the limits of civility may well have been transgressed. Kremen $v$. United States 215 might be read as a triumph of the proprietary right of privacy, not inconsistent with the weight given that right in Frank. In Kremen the seizure of the entire contents of defendant's cabin served no clear societal purpose. Neither the fact that the search and seizure were made incident to lawful arrest nor the certainty that the defendants were guilty of crime could compensate for the slight utility of the invasion.

But the similarity of results in extreme cases does not hide the fact that calculus determination might often vary from the results reached by inflexible standards in normal circumstances. Most cases involving search for evidence of crime would not be disposed of by those considerations which impose absolute standards. They would find their way to the balance and there would be treated in a revolutionary manner. For the first time the seriousness of the crime would be a relevant factor. It is possible that something short of probable cause to arrest and arraign would legitimize investigative techniques involving minor trespasses.

At this point the central problem in the conceptual scheme arises. A calculus requires quantitative assessments of relevant circumstances in a search. More important, it demands that an initial weighting factor be assigned to each of the determinants. Injury to reputation, for example, might exert more or less weight than would trespass on private property. But if the reasonableness clause, which supports such a calculus, be cut adrift from the warrant requirements of the amendment and from the guidance they supply, how are the courts to weight the interrelated interests bearing on search and seizure? Common law techniques may be equal to the task. Ideally, however, the courts could look to guidance from the legislatures, the branch of government which can best presume to reflect the assessments of the community. The introduction of a calculus might thus encourage Congress to enter an area from which the rigidities of the warrant have previously excluded it, 216 and to relieve the fourth amendment from day to day pressures greater

214342 U.S. 165 (1952).

215353 U.S. 346 (1957).

216 Legislative involvement in the area is rare. The most common exceptions are statutes which withhold the right to secure search warrants to investigate specific types of activity or which limit the scope of the writ. For a comprehensive collection of such congressional enactments, see Appendix to Davis v. United States, 328 U.S. 582, 616 (1946) (Frankfurter, J., dissenting). A rare example where Congress lowered the probable cause requirement, and authorized warrantless searches can be found in the enactments of the first Congress 
than it can bear. No judicial abdication would be involved. The outer limits on search and seizure techniques would be safeguarded by the Constitution and enforced by the courts. Variations in calculus weightings within those limits could be only as broad as the area in which reasonable men may differ.

That Rabinowitz, Frank, and Abel sowed the seeds of such a revolution in search and seizure law appears clear. That those seeds will come to fruition in the manner suggested may be doubtful. Nevertheless, present patterns of search and seizure practice cannot be reconciled with official theory. The bed is too short and the covers too narrow.

regarding inspection of vessels. Act of July 31, 1798, ch. 5, § 24, 1 Stat. 29, 43. Like provisions are found in the Act of August 4,1790, ch. 35, $\$ 48-51,1$ Stat. 145, 170; Act of February 18,1793 , ch. 8, $\$ 27,1$ Stat. 305, 315; Act of March 2, 1799, ch. 22, $\$ 68-71,1$ Stat. 627, 677, 678. The National Prohibition Act contained carefully worked out provisions regarding search. For example, dwellings were immune from warranted searches unless being used for the sale of illicit liquor. 41 Stat. 305, 315 (1919). In Carroll v. United States, 267 U.S. 132 (1925), the act was construed to authorize the warrantless search of moving vehicles.

Involvement of state legislatures has taken a variety of forms. A few statutes have attacked the exclusionary rule rather than substantive standards. Michigan, for example, has eliminated the exclusionary rule in narcotics and possession of weapons cases. Mich. CoNsT. art. II, $\S 10$, as amended in 1936 and 1952. Maryland, attacked the problem at the other end by adopting legislation which made illegally obtained evidence inadmissible in misdemeanor cases, retaining admissiblity in felony cases. Then, the statute was amended to permit illegally secured evidence to be admitted in certain misdemeanor cases when prosecuted in particular counties. MD. ANN. CODE art. 35, $\$ 5$ (1957). Cf. Salsburg v. Maryland346 U.S. 545 (1954). These efforts would seem to be misdirected; they attack one form of illegality by fostering another - the latter on the part of law enforcement officers themselves. See Allen, The Wolf Case: Search and Seizure, Federalism, and the Civil Liberties, 45 ILL. L. REV. 1, 19 (1950).

Legislative attacks on the substantive problem have also been attempted. (1) The Uniform Arrest Act $\S 3$ provides for frisking of persons detailed under $\S 2$ (which provides for a two hour period of detention of suspected persons) upon reasonable grounds to believe that the person is carrying a weapon. Warner, The Uniform Arrest Act, 28 VA. L. REv. 315 (1942). (2) The Uniform Narcotic Drug Act $\$ 23$ (See, e.g., IIL. REv. STAT. ch. 38, § 192.28 (1959)) gives narcotics officers the power "without a warrant, to enter and examine all buildings, vessels, cars, conveyances, vehicles or other structures or places, and to open and examine any box, barrel, parcel, package, or other receptacle in the possession of any common carrier, which they have reason to believe contains" illicit narcotic drugs. (3) Many states have given officers visitation rights in premises licensed (most commonly liquor establishments) by the state. The rights are justified on a theory of reasonable conditions upon the grant of a state privilege, or on a theory of consent. The Illinois Liquor Control Act, for example, authorizes officers "to enter at any time upon any premises licensed hereunder to determine whether any of the provisions of this Act or any rules or regulations ... have been or are being violated" (the regulations incorporate all of the laws of the state). ILL. REv. STAT. ch. 43, § 190 (1959) and regulations thereunder.

The language of Mr. Justice Jackson in United States v. Di RE, 332 U.S. 581, 585 (1948), should be added encouragement to Congress to enter the field of search and seizure which it has so long neglected: "Obviously the Court should be reluctant to decide that a search thus authorized by Congress was unreasonable and that the Act was therefore unconstitutional ... especially when it turns on what is 'reasonable'...." 